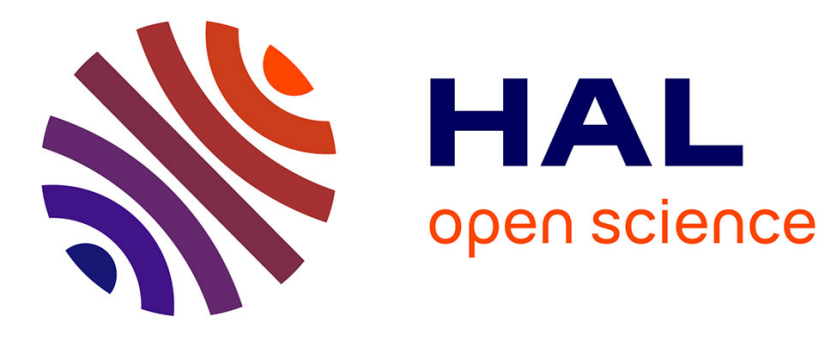

\title{
The Contribution of Payroll Taxation to Wage Inequality in France
}

Malka Guillot, Antoine Bozio, Thomas Breda

\section{To cite this version:}

Malka Guillot, Antoine Bozio, Thomas Breda. The Contribution of Payroll Taxation to Wage Inequality in France. 2020. halshs-01294599v2

\section{HAL Id: halshs-01294599 \\ https://shs.hal.science/halshs-01294599v2}

Preprint submitted on 5 Jun 2020

HAL is a multi-disciplinary open access archive for the deposit and dissemination of scientific research documents, whether they are published or not. The documents may come from teaching and research institutions in France or abroad, or from public or private research centers.
L'archive ouverte pluridisciplinaire HAL, est destinée au dépôt et à la diffusion de documents scientifiques de niveau recherche, publiés ou non, émanant des établissements d'enseignement et de recherche français ou étrangers, des laboratoires publics ou privés. 


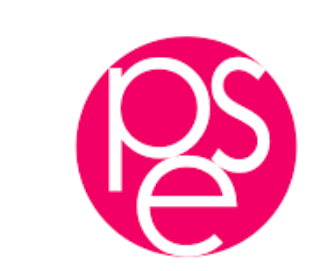

PARISSCHOOL OFECONOMICS
ECOLE D'ECONOMIE DE PARIS

WORKING PAPER № $2016-05$

The Contribution of Payroll Taxation to Wage Inequality in France

Antoine Bozio

Thomas Breda

Malka Guillot

JEL Codes: I24, J24, J31

Keywords: wage inequality, labor cost, payroll tax, Social Security contributions, tax

incidence

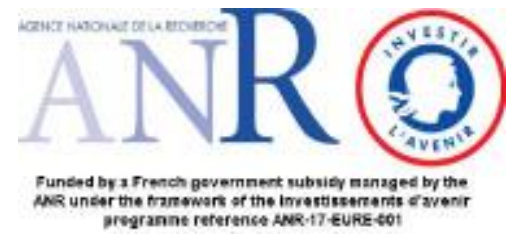




\title{
The Contribution of Payroll Taxation to Wage Inequality in France
}

\author{
Antoine Bozio, Thomas Breda and Malka Guillot*
}

Tuesday $2^{\text {nd }}$ June, 2020

\begin{abstract}
Over the 1967-2015 period, net wage inequality has decreased in France by 25\%, in contrast to the significant increase experienced by most developed countries. Less well known is the fact that labor cost inequality has actually increased by $8 \%$ over the same period. We show that, (a) standard demand-side explanations for the rise in inequality apply in France when tested using measures of labor cost (as they should be); (b) reforms to payroll taxation, jointly with increases in the minimum wage, can explain a large part of the decrease in net wage inequality, in the context of increasing market inequality.
\end{abstract}

Keywords: wage inequality, labor cost, payroll tax, Social Security contributions, tax incidence

JEL codes: I24, J24, J31.

*Bozio: Paris School of Economics (PSE), antoine.bozio@ipp.eu. Breda: PSE, thomas.breda@ens.fr. Guillot: ETH Zürich, malka.guillot@gess.ethz.ch. We thank Luc Behaghel, Steve Machin, Alan Manning, Eric Maurin, Andreas Peichl, Thomas Piketty, Ariell Reschef, Emmanuel Saez and Stefanie Stantcheva for useful comments and discussions. We also thank for their feedback seminar and conference participants at CREST, PSE, Dares, EALE, EEA and ESPE as well as the members of the research consortium from PSE, IFS, DIW and CPB. We acknowledge financial support from Agence nationale de la recherche (ANR) within the Open research area (ORA) framework under the grant number ANR-12-ORAR-0004. 


\section{Introduction}

A large literature has documented a significant increase in wage inequality in many developed countries since the 1970s. Studies on U.S. data have shown a very steep increase in overall wage inequality in the 1980s (Bound \& Johnson 1992; Katz \& Murphy 1992 and Katz \& Autor 1999 for a survey), a continued increase in the upper half of the distribution in the 1990s, while the widening of the wage inequality halted in the bottom half of the distribution during that period (Autor et al. 2008). A similar pattern has been found for the U.K., for Germany and most other OECD countries (Gosling et al. 2000, Dustmann et al. 2009).

France is the only large developed country that has not been subject to these secular trends: wage inequality has been decreasing over the past 50 years all over the wage distribution, except at the very top (Koubi et al. 2005, Charnoz et al. 2011, 2013, Verdugo 2014, Godechot 2012). This "French exception" casts doubts on the main demand-side explanations for the rise in wage inequality, such as technological change (Katz \& Murphy 1992, Autor et al. 1998, Card \& Lemieux 2001, Autor et al. 2008), job polarization (Autor et al. 2006, Goos \& Manning 2007, Goos et al. 2009, Autor 2015) or globalization (Feenstra \& Hanson 1999), which have concerned all developed countries, including France. Studies of the French wage structure found mixed results regarding the existence of Skill-Biased Technical Change (SBTC) or technology-induced job polarization in France, and suggested that institutional factors - in particular expansion of education and the minimum wage have been the main drivers for the compression of the wage distribution (Goux \& Maurin 2000, Charnoz et al. 2011, Card et al. 1999, Verdugo 2014).

In this paper, we revisit the French evidence with a simple (but often forgotten) argument, i.e., that the relative demand for skilled and unskilled labor depends on their relative product wages (or labor costs), which includes payroll taxation, rather than their relative gross wage, or posted wages. ${ }^{1}$ For many countries, the difference is small and only marginally changes the overall picture on widening inequality. For instance, in the U.S., the combination of a small increase in employer payroll tax $(+1.6 \mathrm{ppt})$ and a relatively high payroll tax threshold (around P90) over the period 1970-2010, means that labor cost

\footnotetext{
${ }^{1}$ To clarify we call gross wage the posted wage specified in the labor contract, and labor cost the cost to the employer including payroll taxes. Other studies of the French labor market are aware of the importance of considering labor costs when studying the role of demand-side factors in this country (e.g., Goux \& Maurin (2000), Charnoz et al. (2011)). None of the existing studies, however, provides a comprehensive analysis of the changes in payroll taxation and their redistributive impact over the last fifty years.
} 
inequalities are only marginally different from gross wages inequality. ${ }^{2}$

The picture is very different in France, where payroll taxes are substantial (around 17\% of GDP) and have changed dramatically over time and across the wage distribution. France has the highest employer payroll tax rate among OECD countries, with total employer marginal rates close to $40 \%$ of gross earnings under the Social Security threshold. However, during the 1980s and 1990s, two sets of policies have radically transformed the distribution of employer payroll taxation: first, in the 1980s, a number of these payroll taxes have been "uncapped", i.e., also applied to earnings above the threshold. Second, during the 1990s, reductions in employer payroll taxes around the level of the minimum wage have been implemented. As a result, employer payroll taxes have been reduced on low earners and increased on high earners, leading to a very different picture of wage inequality whether one uses product wage or net wage concepts. Using administrative data spanning from 1967 to 2015, we show that labor cost inequality has actually increased in France by 8\%, while net and gross wage inequalities have decreased by about $25 \%$.

Using labor cost measures of wage inequality, we revisit the role of technological change in France. We first provide indirect evidence of SBTC following the supply/demand framework developed by Katz \& Murphy (1992). We then provide more direct evidence on the contribution of ICT to job polarization following Michaels et al. (2014). The two approaches lead us to conclude that technology has increased inequality and polarized employment in France and in other countries to a comparable extent. This conclusion is less clear-cut when the empirical analyses are done with net or posted wages instead of labor costs. This highlights the importance of using the appropriate wage measure when studying the contribution of demand-side factors to the rise in wage inequality.

If the French case is not an exception that can be used to challenge the role played by technological change in developed countries, it also exemplifies the fact that institutional factors, like the minimum wage and taxation, can have powerful impacts on the evolution of net wage inequality. The wage inequality literature has mostly examined the role of institutions such as the minimum wage, unionization, or education policies, often with the U.S. experience (DiNardo et al. 1996, Autor et al. 2016). We show that the French policy mix - targeted cut in payroll taxes and increases in the minimum wage - can be credited for a large part of the observed reduction in net wage inequality in France at a time of

\footnotetext{
${ }^{2}$ According to our computations, inequalities computed with the two concepts are virtually equal except for workers in the top decile of the distribution who were partly caught up by the payroll tax threshold. These computations do not include non-mandatory contributions (e.g., health insurance, employer contributions to pension funds) or fringe benefits that may also be included in total compensation as in Pierce (2001, 2010).
} 
increasing product wage inequality. It can be seen as an alternative to the working tax credits or EITC-like schemes put in place in many countries, notably the U.S. or the U.K, to support net wage of low earners (Hoynes \& Patel 2018, Brewer \& Hoynes 2019). The use of payroll taxation can mitigate the detrimental employment impact of high minimum wage regulations, while using a minimum wage can guarantee that lower taxation of lower earners is not captured by employers in the form of even lower wages (Rothstein 2010, Azmat 2019).

The rest of the paper is organized as follows: Section 1 presents the data, the reforms to payroll taxation and our measures of net wage and labor cost inequality in France over the period 1967-2015. Section 2 reassesses the role of technological change using labor cost per worker instead of gross or net wage. Section 3 discusses the impact of the minimum wage and payroll tax reforms on the evolution of wage inequality. Section 4 concludes.

\section{Payroll Taxation and Labor Cost Inequality}

In this section, we briefly describe the institutional setting and the data we use, before presenting basic results on labor cost inequality in France over the 1967-2015 period.

\subsection{Reforms to Payroll Taxation in France}

Payroll taxes are a very important part of taxation in France representing close to $40 \%$ of total tax revenues. ${ }^{3}$ During the period covered by our data (1967-2015), many payroll tax reforms have been carried out in France. Figure 1 offers an overview of these, by showing the average payroll tax rate, expressed as a fraction of the labor cost, for P10, P50, and P90 of the earnings distribution. ${ }^{4}$

Two periods stand out: from 1967 to the mid-1990s, the average payroll tax rates at P90 increased sharply from 21 to $47 \%$ and eventually caught up the rates at P50 and P10. This is explained by two types of reforms: first, a gradual increase in the rate below the main Social Security threshold from 30 to $45 \%$; second a partial uncapping of payroll taxes above the threshold. Both types of reforms increased the total amount of contributions collected, leading to a very high contribution wedge of almost $45 \%$ of labor cost for most wage earners in the mid-1990s. This means that studies based on net earnings for this period ignore almost half of total labor costs.

\footnotetext{
${ }^{3}$ See Appendix A for a comprehensive summary on payroll taxes in France.

${ }^{4}$ In Appendix, Figure D1 presents additional details across the entire earnings distribution.
} 
The second period, spanning from the mid-1990s to the present day, has attracted more attention. Average payroll tax rates stabilized at around $46 \%$ of labor cost for the top half of the earnings distribution while they dropped for lower percentiles (to $34 \%$ for the tenth percentile). This is the result of policies aiming to reduce labor cost at the minimum wage by cutting employer payroll taxes. Those payroll tax cuts started for workers whose wage was below 1.1 times the national minimum wage. They have been progressively extended to higher levels of the wage distribution, up to 1.6 times the national minimum wage. These reforms were motivated by the idea that a high minimum wage combined with high employer payroll taxes were detrimental to employment. They have been widely studied to assess their efficiency in terms of employment (e.g., Kramarz \& Philippon 2001, Crépon \& Desplatz 2001).

\subsection{Data and Wage Concepts}

Data. Our main analyses rely on Social Security records called Déclarations annuelles de données sociales (DADS). DADS are individual-level annual earnings data that each employer needs to fill for each employee. We use a panel version of DADS which covers a 1/25 sample of all employees from 1967 to 2001, and a 1/12 of all workers from 2002 onwards. To build time series by skill level, we supplement these data with information on education from the census, available for the period 1976-2015 for a subsample of workers from the DADS called DADS-EDP. ${ }^{5}$

Sample restrictions. The rules for computing the numerous distinct payroll taxes are rather complex in France, as they depend on hourly wage, firm size, location of the firm, and affiliation to different pension schemes. The panel DADS provides information about the firm (identifier, sector, size), and each job spell (start and end date, earnings, occupation, part-time/full-time). However, one serious limitation of the data before 1993 is the absence of hours of work, implying that we cannot compute payroll taxes for those working parttime before $1993 .{ }^{6}$ Consequently, we focus on workers working full-time in the same firm an entire calendar year.

Wage concepts. The raw data about earnings come under the form of annual "net taxable earnings" (earnings reported for income tax). This definition of earnings is net of

\footnotetext{
${ }^{5}$ Details about the data are provided in Appendix B.

${ }^{6}$ This is because the payroll tax thresholds are proportional to the number of hours worked and are therefore unknown when hours of work are missing.
} 
payroll taxes and gross of income tax. Earnings reported include basic earnings, as well as bonuses. This is our net wage concept for full-time workers observed an entire year in the same firm.

Gross wage corresponds to net wage plus all employee payroll taxes Gross wage is the contractual wage: it corresponds to the amount of pay stipulated in labor contracts, i.e., the posted wage, and on which negotiations typically take place. Gross wages are available in the DADS from 1993 onward. Before that date, we have computed them from the net wage using TAXIPP, the tax simulator of the Institut des politiques publiques.

We call labor cost the actual cost paid per day worked full time by a firm for a given worker. It includes both employer and employee payroll taxes and has been entirely computed from net wages using TAXIPP.

Our measure of net wage concept from the DADS data is gross of income tax. Given that French income tax is based on joint taxation, we estimate net-of-income tax wage assuming that workers live in one-individual household and have no other source of income. These assumptions lead to approximations but will allow us to provide a broad comparison of the evolution of the payroll tax and income tax schedules.

\subsection{Net Wage and Labor Cost Inequality in France (1967-2015)}

Reductions in Net Wage Inequality, Increases in Labor Cost Inequality. Figure 2a shows the evolution of the ratio P90/P10 for the net wage, gross wage, and labor cost distributions for males and females working full-time full-year over the period 1967$2015 .^{7}$ Regarding net and gross wage inequality, we confirm the decline documented in previous studies (Koubi et al. 2005, Charnoz et al. 2011, 2013, Verdugo 2014). According to our calculations, the ratio P90/P10 declined by $25 \%$ for both wage measures, from about 3.65 in 1967 to around 2.90 in 2015. Most of the decline occurred before 1980; net wage inequality only declined slightly after that date.

In contrast with these trends, labor cost inequality, measured also using the P90/P10 ratio, has increased by $8 \%$ during the period 1967-2015. This overall increase hides a clear U-shaped profile: labor cost inequality first decreased from 1967 to 1980 and then increased sharply-by $30 \%$ over the period 1980-2015, which is similar to the increase observed in the U.S. over that period. ${ }^{8}$

\footnotetext{
${ }^{7}$ Gender is only available in the data after 1975 . Our main results after that date are robust to restricting the analysis to males only (to limit labor force participation effects).

${ }^{8}$ In Appendix, we present the cross-country evidence in Table D1 and Figure D2.
} 
Linking Diverging Inequality Trends to Payroll Taxation. To understand the role played by payroll tax reforms in explaining the diverging trends between net wage and labor cost inequality, three sub-periods should be distinguished. The first period is 1967-1980. During that period, the ratios P90/P10, P90/P50 and P50/P10 exhibit parallel trends for both wages and labor costs. This is because average payroll tax rates evolve roughly similarly in all wage deciles between 1967 and 1980 (cf. Figure 1).

The second period is 1980-1993. During that period, payroll taxes are progressively uncapped and the average rate at P90 increases faster than it does at P50 and P10. As a consequence, the gap between wage and labor cost inequality starts to narrow. The convergence between net wage inequality and labor cost inequality is entirely driven by the upper-tail of the distribution (Figure 2c).

The third period starts in 1993. From that year onwards, the average payroll tax rate at P10 starts to decrease due to payroll tax reductions for low wage earners. From 1993 onwards the ratio P50/P10 increases for labor costs and departs from the ratios observed for net and gross wages (Figures 2b). As a consequence, during the period 1993-2015, labor cost inequality increases in both the upper and the lower tail of the distribution of labor costs.

\section{Market-Driven Explanations of the Rise in Wage Inequality}

In this section, we assess the traditional market explanation for the increase in wage inequality, namely the relative shifts in the demand and supply for skilled labor. Using labor cost inequality measures, we show that the French experience reinforces the case for a large global demand shift in favor of skilled workers. We also document direct evidence of skill-biased technical change underlying these increasing inequality trends.

\subsection{A Demand Shift Towards Skilled Workers.}

To test for the existence of a demand shift towards skilled workers, we estimate a version of the macro-level supply/demand model initiated by Katz \& Murphy (1992). In this approach, the evolution of the demand for skilled workers is identified from the long-term changes in the relative labor cost of skilled and unskilled workers that cannot be explained by changes in their relative supply. As most developed countries, France has experienced 
a large expansion of higher education in the past fifty years, leading to an increase in the supply of workers with at least some college education relative to those with a high-school degree or less. For example, while in 1976, the former group (the "high-skilled" workers) comprised $20 \%$ fewer workers than the group of workers having only completed high school (the "middle-skilled" workers), it outnumbered it by 60\% in 2015 (Figure 3a). Absent any change on the demand side, this increase in the relative supply of skilled workers should have led to a decrease in their relative labor cost. In contrast with this prediction, the relative labor cost of skilled workers actually increased, which therefore suggests a positive shift in the relative demand for them has also taken place during the same period.

To test more formally that such a demand shift has occurred, we adapt the framework of Autor et al. (2008) and assume that aggregate output $Q$ depends on three labor inputs, high-skilled $(h)$, middle-skilled $(m)$ and low-skilled $(l)$ according to the following CES production function:

$$
Q_{t}=\left[\left(a_{t} N_{h t}\right)^{\rho}+\left(b_{t} N_{m t}\right)^{\rho}+\left(c_{t} N_{l t}\right)^{\rho}\right]^{1 / \rho}
$$

where $N_{h t}, N_{m t}$ and $N_{l t}$ are the quantities of high-skilled (at least some college), middleskilled (high-school graduates) and low-skilled (high school dropouts) workers in period $t$. $a_{t}, b_{t}$ and $c_{t}$ are technical change parameters augmenting high-skilled, middle-skilled and low-skilled labor inputs. $\sigma=\frac{1}{1-\rho}$ is the elasticity of substitution between the three types of workers. SBTC hypothesis implies that $a_{t} / b_{t}$ increases over time.

Assuming that the labor cost (and not their net or gross wage) associated to both high-skilled and middle-skilled workers are equal to their marginal products, we can derive from equation (1) the following relation:

$$
\ln \left(\frac{z_{h t}}{z_{m t}}\right)=\frac{1}{\sigma}\left[D_{t}-\ln \left(\frac{N_{h t}}{N_{m t}}\right)\right]
$$

where $z_{h t}$ and $z_{m t}$ are the labor costs associated with skilled and unskilled workers and $D_{t}=(\sigma-1) \ln \left(a_{t} / b_{t}\right)$ represents relative demand shifts favoring skilled workers. The impact of changes in relative skill supplies on relative wages depends inversely on the magnitude of $\sigma$, the aggregate elasticity of substitution between the two skill groups. It is common in the literature to approximate $D_{t}$ by a time trend, and possibly to add control variables such as the minimum wage or the unemployment rate. This leads to the following empirical model: 


$$
\ln \left(\frac{z_{h t}}{z_{m t}}\right)=\beta_{0}+\beta_{1} t+\beta_{2} \ln \left(\frac{N_{h t}}{N_{m t}}\right)+\beta_{3} X_{t}+\varepsilon_{t}
$$

We have estimated variants of equation (3). ${ }^{9}$ In the simplest specification without any control variable, we find $\beta_{2}=-0.29$, corresponding to an elasticity of substitution between high-skilled and middle-skilled workers of 3.5, which is larger than what is typically found for the U.S., but consistent with the estimates obtained by Verdugo (2014) for France. Estimates of $\beta_{1}$ are also positive and significant, consistent with the existence of a demand shift toward skilled workers. This result is robust to controlling for the minimum wage and the unemployment rate.

To illustrate the mistake that one makes using net wage instead of labor cost to capture changes in demand, we have also estimated equation (3) using relative net wages as the dependent variable. In such a model, we still find evidence of a significant demand shift for skilled workers, but its magnitude is under-estimated by $30 \%$ while the elasticity of substitution between skill groups is over-estimated by around $20 \%{ }^{10}$

Wrapping-up. The magnitude of demand shifts toward high-skilled workers estimated in France over the past fifty years is comparable to estimates for the U.S. and the U.K., consistent with the idea that technological change should have hit developed countries to a similar extent. The increase in the relative supply of skilled workers in France is also comparable to that observed in the U.S. and the U.K. ${ }^{11}$ Together, these comparisons imply that supply and demand forces are likely to have affected wage inequality across skill groups similarly in France and in other developed countries. Therefore they cannot explain the decrease in net wage inequality observed in France.

\subsection{Direct Evidence of Skill-Biased Technical Change.}

A limit of the macro supply/demand model above is to capture changes in demand without relating them directly to their potential causes. To show direct evidence of skilled-

\footnotetext{
${ }^{9}$ Results are available in Appendix in Table D2.

${ }^{10}$ Low-skilled and middle-skilled workers are often considered together in the seminal supply/demand model à la Katz \& Murphy (1992). We chose to consider them separately because the evolution of lowskilled wages in France is likely to be strongly influenced by the minimum wage and because research on job polarization has shown that middle-skilled workers are likely to have suffered more than low-skilled ones from automation. Nevertheless, we show in Panels (b) and (c) of Table D2 that results are very similar when we consider middle-skilled workers instead of low-skilled workers in equation 3 , or when we group together low- and middle-skilled workers.

${ }^{11}$ See Appendix, Figure D3.
} 
biased technical change, an appealing approach followed by Michaels et al. (2014) consists in showing that the share of total labor costs accruing to skilled workers increased relatively more in countries and/or industries that experienced the largest increases in their Information and Communication Technologies (ICT) capital. Such empirical findings are indeed consistent with a stronger complementary in production between skilled workers and ICT capital than between other types of workers and ICT capital. This is exactly the idea of skill-biased technical change.

Using the EUKlems data matched with the DADS data for the period 1978-2015, we have reproduced the analysis of Michaels et al. (2014) for France, using labor costs instead of net wages. Our conclusions are summarized in Figure 3b: sectors that increased the most the share of ICT capital in total value-added are indeed those where the share of total labor costs accruing to skilled workers increased the most. ${ }^{12}$

\section{The Role of the Minimum Wage and Payroll Tax Reforms}

In this section, we discuss the respective role of minimum wage regulation and payroll tax reforms to explain the evolution of net wage inequality in France. We argue that the reduction in wage inequality observed in the 1960s and 1970s can be ascribed, in large parts, to significant increases in the minimum wage. After the mid-1990s, it is the combination of targeted payroll tax cuts and minimum wage increases that explain the decrease in net wage inequality at a time when product wage inequality was rapidly increasing. Once taking into account the contributive nature of some of the payroll tax reforms and issues of incidence, we reach the conclusion that a large part of the reduction in wage inequality observed in France can be ascribed to the policy mix of joint increases of minimum wage and targeted cuts in payroll taxes.

\subsection{Minimum Wage Increases in the 1960s and 1970s}

A minimum gross wage was introduced in France for the first time in 1950. Initially indexed on inflation, it followed from 1970 onwards an index based on the average earnings of blue-collar workers. On top of these rules of automatic revaluations, the government

\footnotetext{
${ }^{12}$ We provide the corresponding empirical estimates in Table D3, and additional details on this replication exercise in Appendix C.2.
} 
could decide additional discretionary increases.

The minimum wage, either expressed in terms of gross wages or converted in a net wage equivalent, grew much faster than the current price index over the period 1967-2015. It increased steadily in real terms (Figure 4a). The largest increase occurred just after the May 1968 events: between 1968 and 1970, the gross (or net) minimum wage increased by almost 50\%. It kept growing fast in the 1970s, before experiencing a stagnation between 1985 and 1994, and growing again, but at a slower pace, between 1995 and 2015.

To study the effect of the minimum wage on wage inequality, we first rely on suggestive graphical evidence. We start by noting that wage inequality decreased sharply in the lowertail of the wage distribution during the period 1967-1985 when the yearly increases in the real minimum wage were the largest. Just like the minimum wage, lower-tail inequality then stagnated over the decade 1985-1994, before decreasing again after 1994, but at a slower pace than in the earlier period. These simple comparisons exploit the fact that the upward (downward) trend in the minimum wage (lower-tail inequality) was not linear and experienced clear breaks over the period we look at.

To better understand the possible effects of these breaks and avoid a basic comparison of common trends, Figure $4 \mathrm{~b}$ shows the de-trended series of the log net minimum wage in real terms and of lower-tail net wage inequality ( $\log$ of P50/P10). The Figure fully confirms that when the minimum wage increases more (less) than usual, lower-tail inequality decreases more (less) than usual. The pairwise correlation $\rho$ between the two series is as small as -0.944 ( $\rho=-0.986$ when trends are not removed). ${ }^{13}$

We also find a large correlation between the year-to-year variations in the real net minimum wage and the year-to-year variations in lower-tail net wage inequality $(\rho=$ $-0.795)$, confirming a tight link between the minimum wage and lower-tail inequality. In contrast, the correlation between year-to-year variations in the minimum wage and uppertail inequality is much smaller ( $\rho=-0.210$, not statistically different from 0$)$, suggesting that we capture a causal impact of the minimum wage in the bottom-half of the wage distribution rather than a spurious correlation between the minimum wage and overall wage inequality.

The sharp decrease in net or gross wage inequality observed in the late 1960s and 1970s is therefore likely to be largely attributable to the large increases in the minimum wage that have taken place at that time. ${ }^{14}$ This conclusion is also consistent with the large

\footnotetext{
${ }^{13}$ Robustness analyses are presented in Appendix, in Figure D4 and Table D4.

${ }^{14}$ The large and permanent increase in the French unemployment rate that started in 1973 may also be related to the minimum wage (see Figure D5).
} 
increase during that period in the share of workers at or close to the minimum wage and in the ratio between the minimum and the median wage (Figure $4 \mathrm{c}$ ).

\subsection{Payroll Tax Cuts at the Minimum Wage in the 1990s}

Employer payroll tax cuts that started to be implemented in the mid-1990s cannot be analyzed separately from the evolution of the minimum wage. Indeed, these reductions have made much easier to increase again the real net minimum wage after a decade of stagnation, and at a time of high unemployment. Increases in the minimum wage concomitant to payroll tax cuts at the minimum wage have actually mechanically shifted part of these reductions to workers. For example, if the payroll tax rate at the minimum wage is reduced by 10 percentage points in a given year, but that the real minimum wage is increased by $10 \%$ the same year, one should consider that payroll tax reductions have been shifted to workers.

We formalize the argument above in the following way. We denote $w_{t}^{\min }, z_{t}^{\min }$ and $\tau_{t}^{\min }$ the real minimum net wage, the real minimum labor cost, and the average payroll tax rate at the minimum wage in year $t$, so that we have $w_{t}^{\min }=z_{t}^{\min }\left(1-\tau_{t}^{\min }\right)$. Payroll tax cuts started to be implemented in 1994, implying that for any $t>1993, \tau_{1993}^{\min }-\tau_{t}^{\min }$ measures the reduction in payroll taxation induced by the successive reforms. To get an idea of how the minimum wage may have mechanically shifted these reductions to workers, we make the counterfactual hypothesis that the net wages of workers paid the minimum wage would have remained constant in real terms in the absence of any change in the minimum wage (they would have evolved like inflation). This hypothesis implies for example that payroll tax cuts are fully incident on employers in the absence of any inflation. We study how the minimum wage may have generated a shift from this benchmark case.

To do so, we plot $\frac{w_{t}^{m i n}-w_{1993}^{m i n}}{\tau_{1993}^{m i n}-\tau_{t}^{m i n}}$ on Figure 4d. This statistic captures the "cumulative" share of the payroll tax reductions that have been mechanically shifted to workers due to changes in the real minimum wage. Results show that, as compared to a counterfactual scenario in which net wages evolve like the inflation and payroll tax cuts are fully incident on firms, more than $50 \%$ of payroll tax cuts had been shifted to employees by the end of the $1990 \mathrm{~s}$, and close to $100 \%$ by the end of the period.

To summarize our analysis for the bottom half of the wage distribution, after a period of falling inequality fostered by large increases of the minimum wage, payroll tax cuts have allowed further decreases in net wage inequality while product wage inequality was rising. 


\subsection{Contributive Versus Non-Contributive Payroll Taxation}

The French Social Security system is heavily influenced by a social insurance model where social benefits are conditioned to past contributions. If the payroll tax reforms that have generated the diverging trend between wage and labor cost inequality have also changed workers' entitlements to benefits, they should not be considered a source of redistribution.

We study this point by distinguishing among the different payroll taxes, those that are really contributive, in the sense that they lead to future benefits (e.g., pensions), from those that are not contributive, in the sense that they fund benefits not directly related to the amount of contribution paid (e.g., health care). ${ }^{15}$ We estimate an "augmented net wage" measure by adding to net wage contributive payroll taxes and subtracting the contributive reductions. This new variable measures the wage received by a worker plus the future benefits she will get from working, assuming that the present value of these future benefits is equal to the contribution paid. ${ }^{16}$

Figure 5a shows that inequality in terms of net wages plus future benefits is close to and has evolved similarly to inequality in terms of net wages. The main divergence comes from the 1990-2000 decade, when payroll tax reforms for top earners have implied higher pension contributions leading to higher future benefits (Bozio et al. 2019).

This implies that most of the diverging trends between net wage and labor cost inequality have been generated by reforms of non-contributive payroll taxes. In that sense, these payroll tax reforms can be assimilated to tax reforms redistributing earnings across workers.

\subsection{Redistribution Through Payroll Taxation}

To estimate the contribution of payroll tax reforms to the reduction of wage inequality in France, one has to grapple with the issue of the long-term incidence of employer payroll taxes: what would have been net wage inequality in the absence of these payroll tax reforms?

\footnotetext{
${ }^{15}$ See Appendix A for details. In a nutshell, this distinction is made possible by the fact that detailed information is available on the different types of contributions, including their associated contribution rate and what they fund.

${ }^{16}$ While this is a simplistic assumption, it avoids entering complicated actuarial computations and making non-verifiable hypotheses on how workers value future benefits.
} 
Counterfactual Net Wage Inequality. In Figure 5b we present two polar cases of counterfactual net wage inequality in the absence of any payroll tax reforms and assuming behavioral responses triggered by these reforms did not affect observed inequality. In the first case (counterfactual 1), we assume that employer payroll taxes are ultimately shifted to workers. With that standard assumption (see Fullerton \& Metcalf 2002, for a survey), the counterfactual net wage inequality follows the labor cost inequality series. In the second case (counterfactual 2), we assume that non-contributory payroll tax increases are entirely passed on firms, while payroll tax cuts after 1993 (observed at P10 only) have been mechanically shifted to workers through the minimum wage in the same proportion as in Figure 4d. In that case, we obtain a milder counterfactual increase in net wage inequality, especially until payroll tax cuts are introduced in the 1990s. The two counterfactual series may be seen as upper and lower bound of the true counterfactual net wage inequality in the absence of the policy mix of increased minimum wage jointly with payroll tax reforms. They lead us to the conclusion that in the absence of this policy mix, net wage inequality would likely have been 15 to $25 \%$ higher in France in 2015.

Quantifying Redistribution Through Payroll Taxation. To gauge the distributive effects of the successive payroll tax reforms in France, we provide a comparison with the income tax. The tax schedules for non-contributive payroll taxes and the income tax are not directly comparable because the income tax is levied at the household level on both labor and capital income. Figure $5 \mathrm{~d}$ is constructed by applying directly the income tax schedule to workers observed in social security records, assuming they have no capital income and they are taxed individually. ${ }^{17}$

In terms of magnitude, the changes in the non-contributive payroll tax schedule observed on Figure 5c are very large: in 1967, low-wage earners were taxed at a $24 \%$ rate, while the rate of contribution reached $5 \%$ at P99 and almost 0 in the very top of the wage distribution. In contrast, in 2015, the rate is close to 0 in the bottom and gets higher than $30 \%$ in the top. These numbers imply that between 1967 and 2015, the difference between the rates of contributions of the highest and the lowest wage earners has moved from a negative -24 percentage points to a positive 30 percentage points. Changes in the income tax schedule have been opposite, with the income tax schedule becoming less progressive over time. Hence, in France, the change of the structure of non-contributive payroll taxation has been the main institutional response to increased market-wage inequality. When

\footnotetext{
${ }^{17}$ As a result, Figure 5 d should be considered as an approximation that only serves as a simplified benchmark for comparison with the payroll tax schedule.
} 
we make simple computations of the respective contributions of payroll and income tax reforms to changes in the total tax wedge, we find that more than $100 \%$ of wage inequality reduction can be ascribed to payroll tax reforms, while income tax changes have had a modest positive contribution to increases in net wage inequality. ${ }^{18}$

\section{Conclusive comments}

We have shown in this paper that net wage inequality in France has been decreasing in the past fifty years due to a large increase in the real minimum net wage combined with reforms reducing payroll taxes for low-wage earners and increasing them for high-wage earners. These policies can explain that, while labor cost inequality started to increase substantially from the mid-1980s in France - as it did during the same period in most developed countries - inequality in terms of net wages actually decreased. We also show that the increase in labor cost inequality can be, at least partly, attributed to a demand shift toward more skilled workers due to their productive complementarity with ICT capital.

We argue in the paper that a substantial redistribution has taken place based on a policy instrument that was not primarily intended to do so, namely payroll tax cuts. We draw some lessons that could apply to other countries. First, payroll taxation and minimum wage can be part of an effective policy mix to reduce wage inequality, while ensuring a minimum pay for work and that lower taxation of lower earners is not captured by employers in the form of even lower wages. A limit of this solution is, however, that it applies to individuals, preventing it to target directly poor families. Second, the French redistributive experience can be characterized as not very transparent to the public-labor unions actually systematically describe employer payroll tax cuts for low wage earners as a gift to firms. Thus, it has helped engineer substantial redistribution without standard political economy issues, but the obvious drawback is that it has fostered large confusion in the public eyes on the real impact of those policies.

\footnotetext{
${ }^{18}$ See Table D5 in Appendix.
} 


\section{References}

Abowd, J. M., Kramarz, F. \& Margolis, D. N. (1999), 'High Wage Workers and High Wage Firms', Econometrica 67(2), 251-333.

Autor, D. H. (2015), 'Why are there still so many jobs? The history and future of workplace automation', The Journal of Economic Perspectives 29(3), 3-30.

Autor, D. H., Katz, L. F. \& Kearney, M. S. (2006), 'The Polarization of the U.S. Labor Market', The American Economic Review 96(2), 189-194.

Autor, D. H., Katz, L. F. \& Kearney, M. S. (2008), 'Trends in U.S. Wage Inequality: Revising the Revisionists', The Review of Economics and Statistics 90(2), 300-323.

Autor, D. H., Katz, L. F. \& Krueger, A. B. (1998), 'Computing inequality: have computers changed the labor market?', The Quarterly Journal of Economics 113(4), 1169-1213.

Autor, D. H., Manning, A. \& Smith, C. L. (2016), 'The Contribution of the Minimum Wage to US Wage Inequality over Three Decades: A Reassessment', American Economic Journal: Applied Economics 8(1), 58-99.

Azmat, G. (2019), 'Incidence, salience, and spillovers: The direct and indirect effects of tax credits on wages', Quantitative Economics 10(1), 239-273.

Bound, J. \& Johnson, G. (1992), 'Changes in the Structure of Wages in the 1980's: An Evaluation of Alternative Explanations', The American Economic Review 82(3), 371392.

Bozio, A., Breda, T. \& Grenet, J. (2019), 'Does Tax-Benefit Linkage Matter for the Incidence of Social Security Contributions?', Working paper.

Brewer, M. \& Hoynes, H. (2019), 'In-Work Credits in the UK and the US: In-work credits in the UK and the US', Fiscal Studies 40(4), 519-560.

Card, D., Kramarz, F. \& Lemieux, T. (1999), 'Changes in the Relative Structure of Wages and Employment: A Comparison of the United States, Canada, and France', The Canadian Journal of Economics / Revue canadienne d'Economique 32(4), 843-877.

Card, D. \& Lemieux, T. (2001), 'Can Falling Supply Explain the Rising Return to College for Younger Men? A Cohort-Based Analysis', The Quarterly Journal of Economics 116(2), 705-746. 
Charnoz, P., Coudin, E. \& Gaini, M. (2011), 'Changes in the French Wage Distribution 1976-2004 : Inequalities within and between Education and Experience Groups', CREST Working Papers (2011-23).

Charnoz, P., Coudin, E. \& Gaini, M. (2013), Une diminution des disparités salariales en France entre 1967 et 2009, in 'Insee Références-Édition 2013, Emploi et salaires'.

Crépon, B. \& Desplatz, R. (2001), 'Evaluation des effets des dispositifs d'allégements de charges sociales sur les bas salaires', Economie et statistique $\mathbf{3 4 8}$.

DiNardo, J., Fortin, N. M. \& Lemieux, T. (1996), 'Labor Market Institutions and the Distribution of Wages, 1973-1992: A Semiparametric Approach', Econometrica 64(5), 10011044 .

Dustmann, C., Ludsteck, J. \& Schönberg, U. (2009), 'Revisiting the German Wage Structure', The Quarterly Journal of Economics 124(2), 843-881.

Feenstra, R. C. \& Hanson, G. H. (1999), 'The impact of outsourcing and high-technology capital on wages: estimates for the United States, 1979-1990', The Quarterly Journal of Economics 114(3), 907-940.

Fullerton, D. \& Metcalf, G. (2002), Tax incidence, in A. Auerbach \& M. Feldstein, eds, 'Handbook of public economics', Vol. 4, Elsevier/North Holland.

Godechot, O. (2012), 'Is finance responsible for the rise in wage inequality in France?', Socio-Economic Review 10(3), 447-470.

Goos, M. \& Manning, A. (2007), 'Lousy and Lovely Jobs: The Rising Polarization of Work in Britain', The Review of Economics and Statistics 89(1), 118-133.

Goos, M., Manning, A. \& Salomons, A. (2009), 'Job Polarization in Europe', The American Economic Review 99(2), 58-63.

Gosling, A., Machin, S. \& Meghir, C. (2000), 'The Changing Distribution of Male Wages in the U.K.', The Review of Economic Studies 67(4), 635-666.

Goux, D. \& Maurin, E. (2000), 'The Decline in Demand for Unskilled Labor: An Empirical Analysis Method and Its Application to France', The Review of Economics and Statistics 82(4), 596-607. 
Hoynes, H. \& Patel, A. (2018), 'Effective Policy for Reducing Poverty and Inequality? The Earned Income Tax Credit and the Distribution of Income', Journal of Human Ressources 53(4), 859-890.

Katz, L. F. \& Autor, D. H. (1999), Chapter 26 - Changes in the Wage Structure and Earnings Inequality, in O. C. Ashenfelter \& D. Card, eds, 'Handbook of Labor Economics', Vol. 3, Part A, Elsevier, pp. 1463-1555.

Katz, L. F. \& Murphy, K. M. (1992), 'Changes in Relative Wages, 1963-1987: Supply and Demand Factors', The Quarterly Journal of Economics 107(1), 35-78.

Koubi, M., Mussard, S., Seyte, F. \& Terraza, M. (2005), 'Évolution des inégalités salariales en france entre 1976 et 2000: une étude par la décomposition de l'indicateur de gini', Economie \& prévision 169(3), 139-169.

Kramarz, F. \& Philippon, T. (2001), 'The impact of differential payroll tax subsidies on minimum wage employment', Journal of Public Economics 82(1), 115-146.

Lindley, J. \& Machin, S. J. (2011), 'Rising wage inequality and postgraduate education', IZA Discussion paper.

Michaels, G., Natraj, A. \& Van Reenen, J. (2014), 'Has ICT polarized skill demand? Evidence from eleven countries over twenty-five years', Review of Economics and Statistics 96(1), 60-77.

Pierce, B. (2001), 'Compensation inequality', The Quarterly Journal of Economics $\mathbf{1 1 6}(4), 1493-1525$.

Pierce, B. (2010), Recent trends in compensation inequality, in 'Labor in the new economy', University of Chicago Press, pp. 63-98.

Rothstein, J. (2010), 'Is the EITC as good as an NIT? Conditional cash transfers and tax incidence', American Economic Journal: Economic Policy 2(1), 177-208.

Verdugo, G. (2014), 'The great compression of the French wage structure, 1969-2008', Labour Economics 28, 131-144. 


\section{Figures and Tables}

Figure 1: Average Payroll Tax Rates in France, at P10, P50 and P90 of the Earnings Distribution

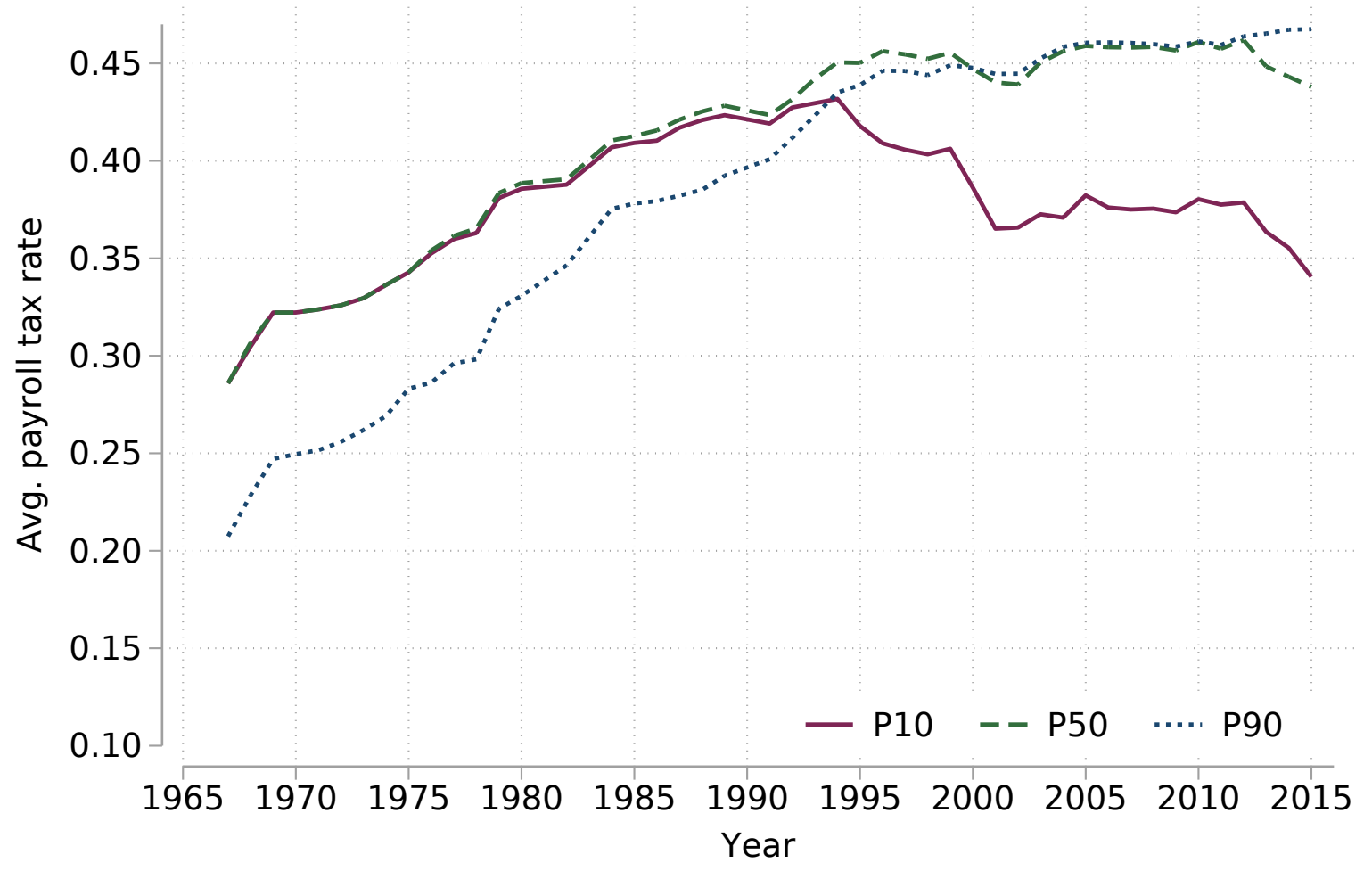

NotE: The figure plots the ratio of the average total payroll taxes (employer and employee part) to the average labor cost for selected percentiles of the labor cost distribution. These ratios are obtained by applying a tax simulator on a sample of men and women, aged between 20 and 64, working in the private sector.

SOURCE: DADS data 1967-2015. 
Figure 2: Wage Inequality Ratios in France, 1967-2015

(a) P90-P10 Ratios

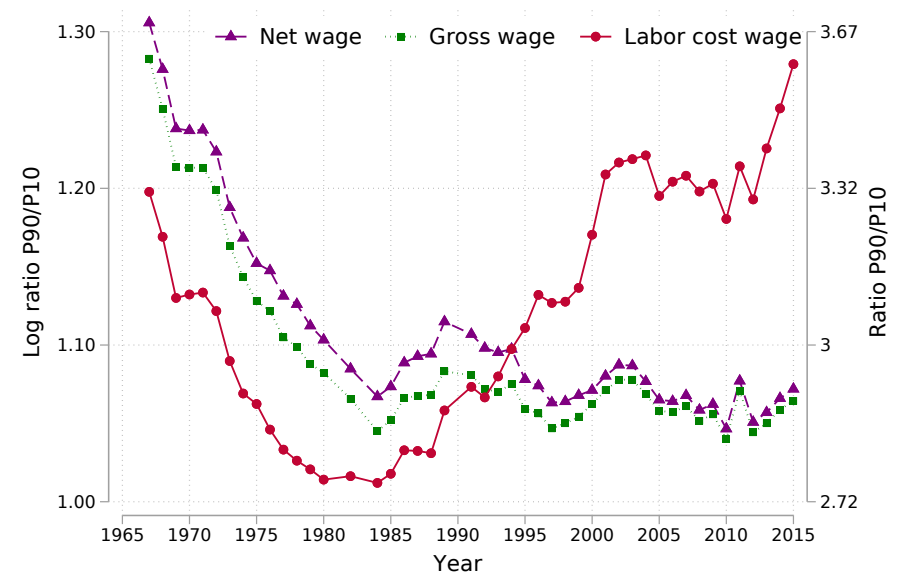

(b) Lower-tail Inequality, P50/P10

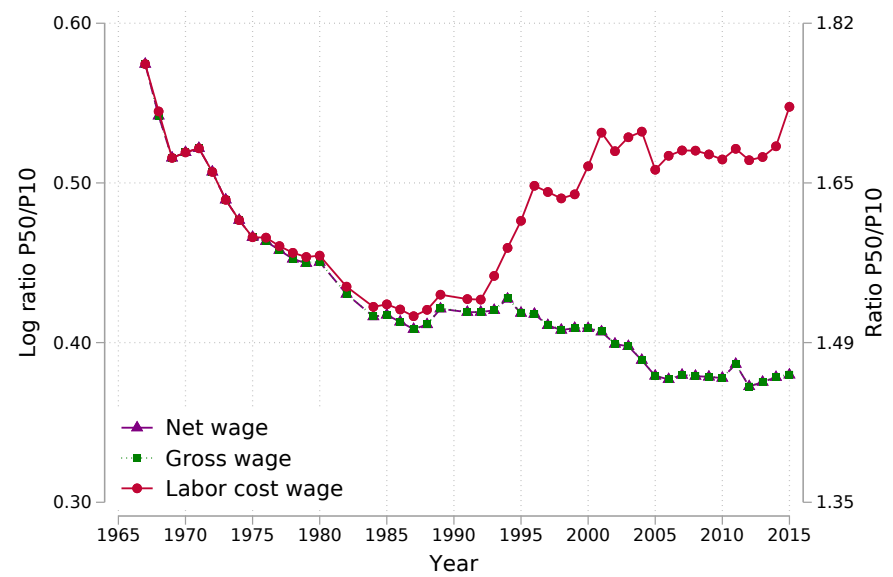

(c) Upper-tail Inequality, P90/P50

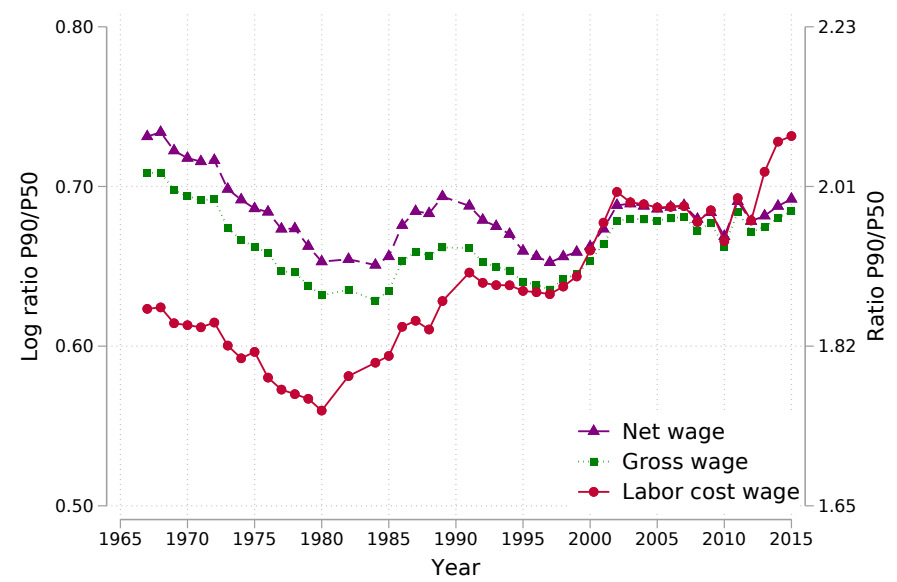

Notes: The figure depicts the log wage ratios P90/P10 (panel a), P50/P10 (panel b) and P90/P50 (panel c) for net, gross and labor cost wages. The sample includes male and female workers of the private sector working full-time and full-year. The right-hand side axis provides the equivalence with the wage ratios. SOURCE: DADS data 1967-2015. 
Figure 3: Evolution of the Demand for Skilled Workers and its Relationship to ICT Capital Investments

(a) Relative Supply vs Relative Wage, Between High-Skilled and Middle-Skilled Workers

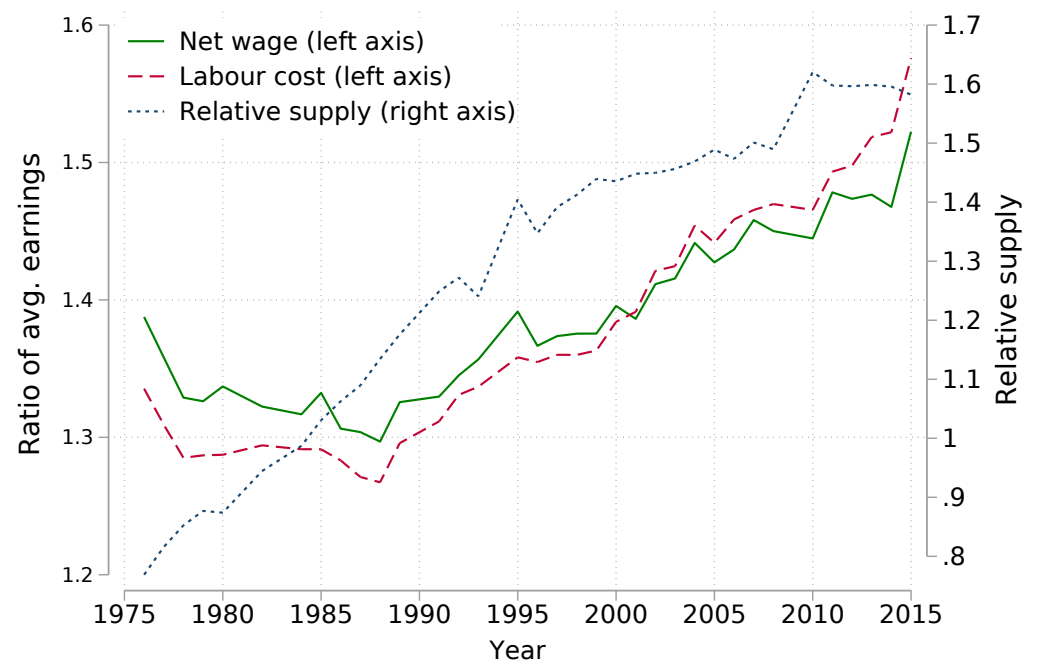

(b) Cross-industry Comparisons of Change in the Wage Bill Share Relative to Changes in ICT Capital, by Workers' Skill
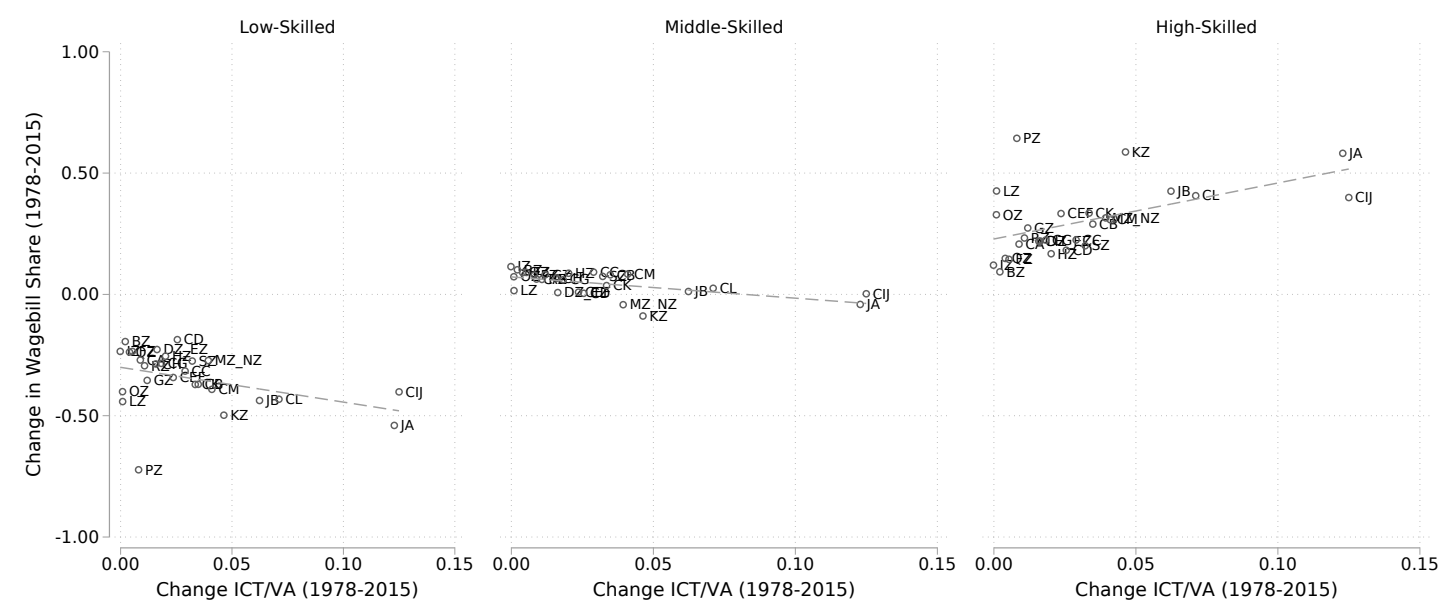

Note: Panel (a) shows the relative wage (in net wage and labor cost) of high-skilled workers (at least some college) relative to middle-skilled workers (high school), alongside the relative supply of these two types of workers. Panel (b) shows the 37-years difference (1978 vs. 2015) in wage bill share of low-, middle- and high-skilled workers (y-axis) with respect to 37-years difference in ICT/VA by sector (x-axis). The dashed lines correspond to the linear fits.

SourCES: DADS-EDP data 1976-2015 (panels a and b). EUKlems data 1978-2015 (panel b). Individuals working full-time full-year in the private sector. 
Figure 4: The role of the Minimum Wage in France, 1967-2015

(a) Evolution of the Minimum Net Wage, Gross Wage and Labor Cost (in Real Terms)

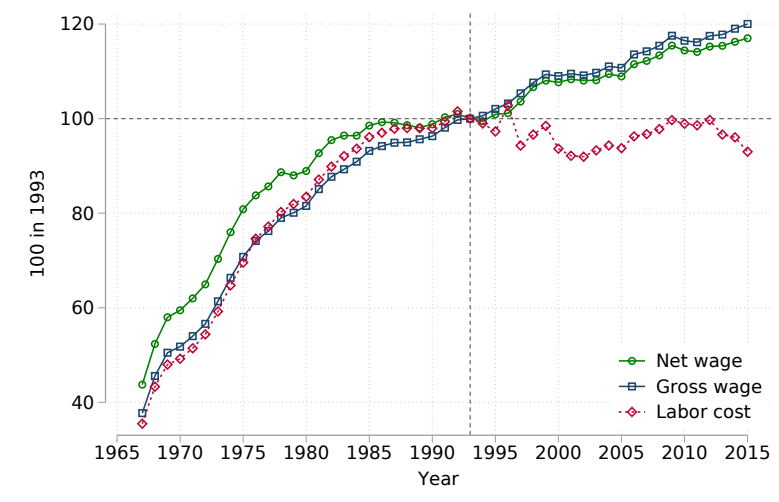

(c) Evolution of the Share of Workers Potentially Affected by the Minimum Wage.

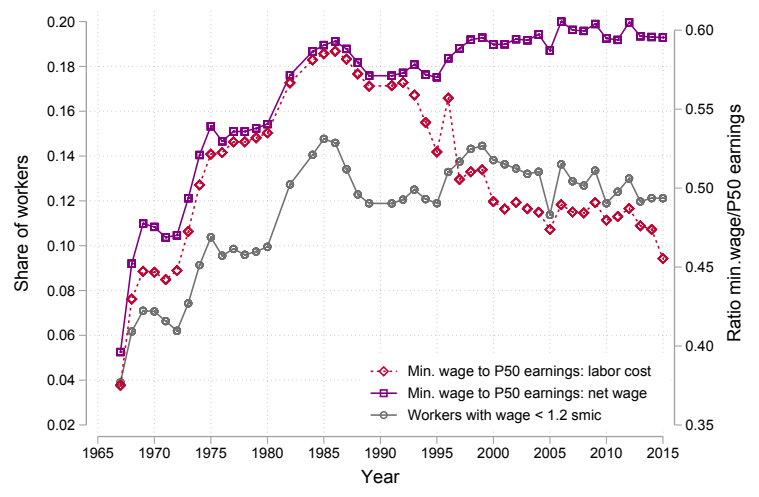

(b) Evolution of the P50/P10 log net Wage Ratio (detrended) and of the log net Minimum Wage in Real Terms (detrended)

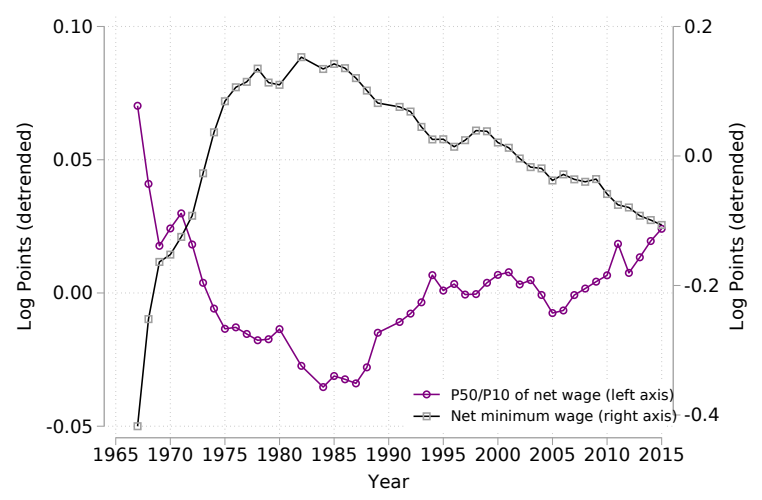

(d) Cumulative Share of the Payroll Tax Cuts at the Minimum Wage Mechanically Shifted to Employees

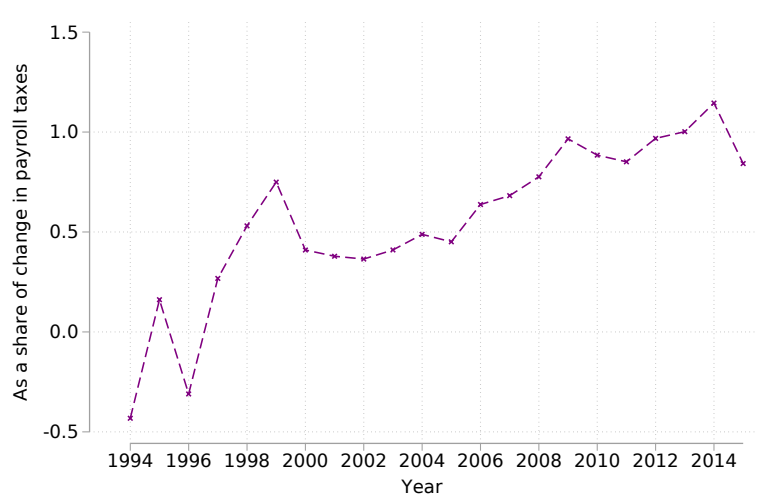

Note: Panel (a) presents the evolution of the minimum wage in real terms (normalized at 100 in 1993) for net, gross and labor cost. Panel (b) shows the detrended time series of the P50/P10 log net wage ratio (left axis) and of the log net minimum wage in real term (right axis). Panel (c) presents the share of workers with a wage inferior to 1.2 the minimum wage (left-hand side). The purple and red lines (right-hand side) are the ratio of the minimum wage to the median wage for the net wage and the labor cost. Panel (d) shows $\frac{w_{t}^{\min }-w_{193}^{\min }}{\tau_{1993}^{m i n}-\tau_{t}^{m i n}}$, that is the cumulative share of the payroll tax changes implemented since 1993 that has been shifted mechanically to workers through minimum wage increases. The reference year is 1993 . We do not take into account the CICE (created in 2013).

SouRCE: DADS data 1967-2015. The sample includes full-time full-year employees paid at the minimum wage in the private sector. 
Figure 5: Redistribution Through Payroll Tax Reforms in France

(a) P90/P10 Wage Inequality Taking into Account Future Benefits and Income Tax

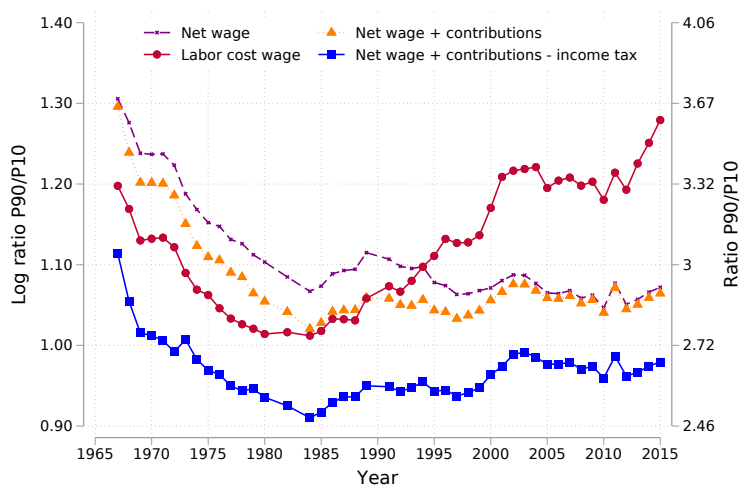

(c) Evolution of the Payroll Tax Schedule Net of Future Benefits

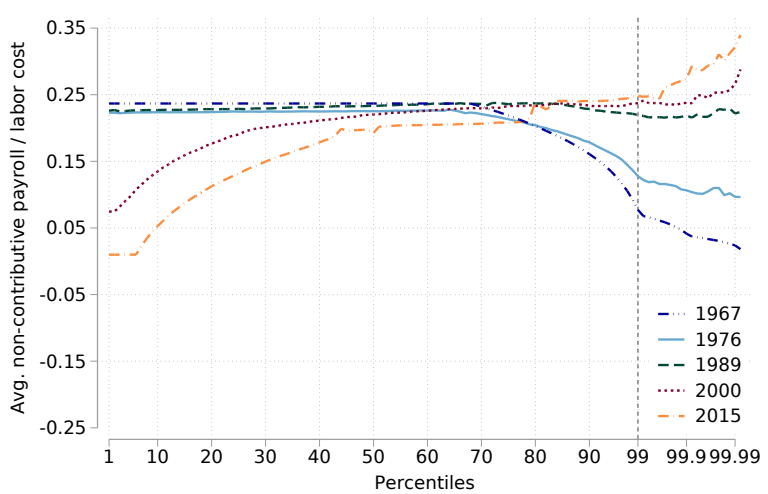

(b) Counterfactual Net Wage Inequality Without Payroll Tax Reforms

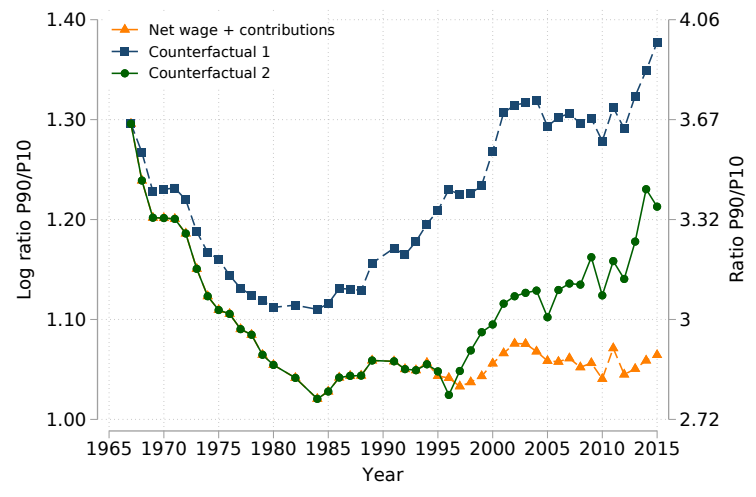

(d) Evolution of the Income Tax Schedule

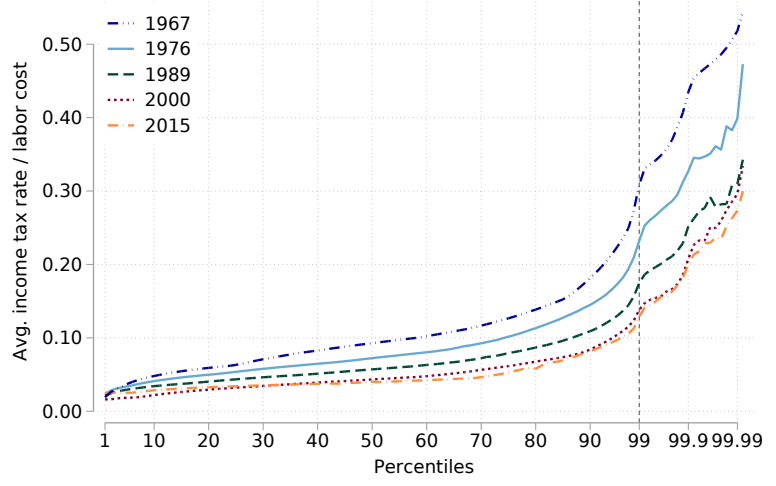

Notes: Panel (a) depicts the P90-P10 log wage ratio for the net wage, the labor cost, the net-of-income tax wage and for a net wage including contributive employer and employee contributions. Panel (b) proposes two scenarios of incidence, on workers or on employers, absent any behavioral responses. Counterfactual 1 assumes that social security changes have been entirely passed on workers whereas counterfactual 2 assumes that non-contributory payroll tax increases have been entirely passed on firms, while payroll tax reductions after 1993 (observed at P10 only) have been mechanically shifted to workers due to the simultaneous increase in the minimum wage in the same proportion as in Figure 4d. Counterfactual 2 is obtained by substracting to the Panels (c) and (d) provide the ratio of two redistributive tools to the average labor cost as the denominator, by percentiles of the labor cost distribution: (panel c) the average non-contributive SSCs from employers and employees to the average labor cost, and (panel d) the average income tax resulting from the simple application of the income tax schedule to the taxable wage. On panel (c) and (d), the vertical line at 99 denotes a change in the x-axis scale. In all panels, the sample includes individuals between 20 and 64 years old working full-time full-year in the private sector.

SourCE: DADS data 1967-2015. 


\title{
(For Online Publication)
}

Appendix to

\section{The Contribution of Payroll Taxation to Wage Inequality in France}

\author{
Antoine Bozio Thomas Breda Malka Guillot
}

February 2020

This Appendix provides complements to institutional details (Appendix A), data (Appendix B), methodology (Appendix C) and additional results (Appendix D).

\section{A Institutional Details on Payroll Taxation in France}

We provide here more details about payroll taxation in France, following closely the detailed description provided by Bozio et al. (2019).

\section{A.1 Structure of the Payroll Tax Schedule}

Basic structure. The French payroll tax schedule follows the same structure for most of the schemes. The tax base is gross (or posted) earnings, with different marginal payroll tax rates corresponding to different thresholds. The reference threshold, which is referred to as the Social Security threshold (SST) (plafond de la securite sociale or PSS, in French), corresponds roughly to mean gross earnings, i.e., around the 70th percentile of the earnings distribution (40,500 euros of gross annual earnings in 2019). The threshold is adapted to the actual hours of work and duration of the job spell, leading to different thresholds for wages expressed in hourly, weekly, quarterly, or annual amounts. For instance, a job spell of only one hour will be subject to a specific hourly threshold. 
Types of payroll taxes. The French Social Security system is composed of a large number of different schemes, each financed through a specific Social Security contribution (SSC). Social Security schemes vary according to the insured risk, and the population covered. The main risks covered by French social insurance schemes are, as in most European countries, old-age pensions, health care, and unemployment insurance. In addition, there exists in France a separate scheme which funds child benefits and child care provisions through employer SSCs. Smaller specific schemes are dedicated to survival benefits, or elderly care.

In addition to SSCs, payroll taxation in France includes other taxes on earnings paid by firms but which do not offer any rights to specific benefits, and These taxes, e.g., the taxe sur les salaires, or literally payroll tax, are not earmarked to Social Security budget and fund general government expenditures. Another example includes a payroll tax dedicated to funding public transport (versement transport), and other smaller payroll taxes fund training or apprenticeship.

Payroll Tax Thresholds. The French payroll tax schedule is composed of four different thresholds (expressed as multiples of the SST) depending on the population consideredthe main distinction being between executives and non-executives in the private sector. For executives, payroll tax rates apply to four wage brackets: (i) below the SST; (ii) between the SST and 4 times the SST; (iii) between 4 times the SST and 8 times the SST; and (iv) above 8 times the SST. For non-executives, payroll tax rates apply to a different splitting of the payroll tax schedule: (i) below the SST; (ii) between the SST and 3 times the SST; (iii) between 3 times the SST and 4 times the SST; and (iv) above 4 times the SST.

Like most payroll tax schedules around the world, French payroll taxes are capped. The main SST is lower in the earnings distribution than in most countries (between P65 or P70 of the earnings distribution) but the upper threshold is much higher. For non-executives, the upper threshold of four times the SST (162,000 euros of gross annual earnings in 2019) corresponds to the 99th percentile of the earnings distribution of full-time wage earners in the private sector. For executives, the upper threshold of eight times the SST $(324,000$ euros of gross annual earnings in 2019) corresponds to the 99.9th percentile of the same earnings distribution.

Table 1 lists the main payroll taxes for a wage earner in the private sector between 1976 and 2010, distinguishing for each scheme the coverage, the legal liability, and the rates that apply to the different earnings brackets. 
Table 1: Payroll Tax Rates in France, Private Sector, 1976-2010

\begin{tabular}{|c|c|c|c|c|c|c|c|c|c|c|c|c|c|}
\hline \multirow{2}{*}{ SSC designation } & \multirow{2}{*}{ French acronym } & \multirow{2}{*}{ Workers concerned } & \multirow{2}{*}{ Legal liability } & \multirow{2}{*}{ Earnings bracket } & & \multicolumn{8}{|c|}{ Rates (in percent) } \\
\hline & & & & & & 1976 & 1980 & 1985 & 1990 & 1995 & 2000 & 2005 & 2010 \\
\hline \multicolumn{14}{|l|}{ Panel A. Pension schemes } \\
\hline Old-age pension scheme & CNAV & all private sector & employee & $<\mathrm{SST}$ & & 3.25 & 4.70 & 5.70 & 7.60 & 6.55 & 6.55 & 6.55 & 6.65 \\
\hline & & $\begin{array}{l}\text { all private sector } \\
\text { all private sector }\end{array}$ & $\begin{array}{l}\text { employer } \\
\text { emplovee }\end{array}$ & $\begin{array}{l}<\text { SST } \\
\text { SSTilng }\end{array}$ & & 7.50 & 8.20 & 8.20 & 8.20 & 8.20 & 8.20 & $\begin{array}{r}8.20 \\
0.10\end{array}$ & 8.30 \\
\hline & & $\begin{array}{l}\text { aul private sector } \\
\text { all private sector }\end{array}$ & $\begin{array}{l}\text { employee } \\
\text { employer }\end{array}$ & $\begin{array}{l}\text { all earnings } \\
\text { all earnings }\end{array}$ & & & & - & - & $\begin{array}{c}- \\
1.60\end{array}$ & $\begin{array}{c}- \\
1.60\end{array}$ & $\begin{array}{l}0.10 \\
1.60\end{array}$ & $\begin{array}{l}0.10 \\
1.60\end{array}$ \\
\hline Widows' pension scheme & VEUVAGE & all private sector & employee & $<\mathrm{SST}$ & & - & - & - & - & - & - & - & - \\
\hline & & all private sector & employee & all earnings & & - & - & 0.10 & 0.10 & 0.10 & 0.10 & - & - \\
\hline \multirow[t]{6}{*}{ Complementary pension scheme } & ARRCO & non-executives & employee & $<\mathrm{SST}$ & & 1.76 & 1.76 & 1.84 & 1.92 & 2.00 & 3.00 & 3.00 & 3.00 \\
\hline & & non-executives & employer & $<\mathrm{SST}$ & & 2.64 & 2.64 & 2.76 & 2.88 & 3.00 & 4.50 & 4.50 & 4.50 \\
\hline & & non-executives & employee & $1-3 \mathrm{SST}$ & & 1.76 & 1.76 & 1.84 & 1.92 & 2.00 & 5.00 & 8.00 & 8.00 \\
\hline & & non-executives & employer & $1-3 \mathrm{SST}$ & & 2.64 & 2.64 & 2.76 & 2.88 & 3.00 & 7.50 & 12.00 & 12.00 \\
\hline & & non-executives & employee & $1-3 \mathrm{SST}$ & & & - & & - & 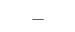 & 8.00 & 8.00 & 8.00 \\
\hline & & non-executives & employer & $1-3$ SST & & - & - & - & - & - & 12.00 & 12.00 & 12.00 \\
\hline \multirow[t]{4}{*}{ Complementary pension scheme } & AGIRC & executives & employee & $1-4 \mathrm{SST}$ & & 2.00 & 2.06 & 2.06 & 2.34 & 5.00 & 7.50 & 7.50 & 7.70 \\
\hline & & executives & employer & $1-4$ SST & & 6.00 & 6.18 & 6.18 & 7.02 & 10.00 & 12.50 & 12.50 & 12.60 \\
\hline & & executives & employee & $4-8 \mathrm{SST}$ & & - & - & - & - & 5.00 & 7.50 & 7.50 & 7.70 \\
\hline & & executives & employer & $4-8$ SST & & - & - & - & - & 10.00 & 12.50 & 12.50 & 12.60 \\
\hline \multirow{6}{*}{ Early retirement complementary pension scheme } & AGFF & all private sector & employee & $<\mathrm{SST}$ & & - & _- & - & - & _- & _- & 0.80 & 0.80 \\
\hline & & all private sector & employer & $<$ SST & & - & - & - & - & - & - & 1.20 & 1.20 \\
\hline & & non-executives & employee & $1-3 \mathrm{SST}$ & & - & - & - & - & - & - & 0.90 & 0.90 \\
\hline & & non-executives & employer & $1-3 \mathrm{SST}$ & & - & - & - & - & - & - & 1.30 & 1.30 \\
\hline & & executives & employee & $1-4 \mathrm{SST}$ & & - & - & - & - & - & - & 0.90 & 0.90 \\
\hline & & executives & employer & $1-4$ SST & & - & - & - & - & - & - & 1.30 & 1.30 \\
\hline \multirow[t]{2}{*}{ Additional complementary pension scheme } & CET & non-executives & employee & 4-8 SST & & - & - & - & - & - & 0.11 & 0.13 & 0.13 \\
\hline & & non-executives & employer & $4-8 \mathrm{SST}$ & & - & - & - & - & - & 0.17 & 0.22 & 0.22 \\
\hline \multicolumn{14}{|l|}{ Panel B. Unemployment insurance } \\
\hline \multirow[t]{4}{*}{ Unemployment insurance scheme } & UNEDIC & all private sector & employee & $<\mathrm{SST}$ & & 0.48 & 0.84 & 1.12 & 1.67 & 2.42 & 2.21 & 2.40 & 2.4 \\
\hline & & all private sector & employee & $1-4 \mathrm{SST}$ & & 0.48 & 0.84 & 1.62 & 2.17 & 2.97 & 2.71 & 2.40 & 2.4 \\
\hline & & all private sector & employer & $<\mathrm{SST}$ & & 1.92 & 2.76 & 2.88 & 3.23 & 4.18 & 3.97 & 4.00 & 4.00 \\
\hline & & all private sector & employer & $1-4 \mathrm{SST}$ & & 1.92 & 2.76 & 2.88 & 3.23 & 4.18 & 3.97 & 4.00 & 4.00 \\
\hline \multirow[t]{4}{*}{ Early retirement scheme } & ASF & all private sector & employee & $<\mathrm{SST}$ & & - & - & 0.80 & 0.80 & 0.80 & 0.80 & - & - \\
\hline & & all private sector & employer & $<\mathrm{SST}$ & & - & - & 1.20 & 1.20 & 1.16 & 1.16 & - & - \\
\hline & & all private sector & employee & $1-4$ SST & & - & - & 0.80 & 0.80 & 0.89 & 0.89 & - & - \\
\hline & & all private sector & employer & $1-4 \mathrm{SST}$ & & - & - & 1.20 & 1.20 & 1.29 & 1.29 & - & - \\
\hline \multirow[t]{4}{*}{ Job placement for executives } & APEC & executives & employee & $1-4 \mathrm{SST}$ & & 0.024 & 0.024 & 0.024 & 0.024 & 0.024 & 0.024 & 0.024 & 0.024 \\
\hline & & executives & employer & $1-4 \mathrm{SST}$ & & 0.036 & 0.036 & 0.036 & 0.036 & 0.036 & 0.036 & 0.036 & 0.036 \\
\hline & & executives & employee & $<\mathrm{SST}$ & & 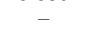 & - & - & - & - & - & - & - \\
\hline & & executives & employer & $<\mathrm{SST}$ & & - & - & - & - & - & - & - & - \\
\hline \multicolumn{14}{|l|}{ Panel C. Health care } \\
\hline \multirow[t]{4}{*}{ Health insurance scheme } & MMID & all private sector & employee & $<\mathrm{SST}$ & & 2.50 & - & - & - & - & - & - & - \\
\hline & & all private sector & employer & $<\mathrm{SST}$ & & 10.45 & 8.95 & - & - & - & - & - & - \\
\hline & & all private sector & employee & all earnings & & 1.50 & 5.50 & 5.50 & 5.90 & 6.8 & 0.75 & 0.75 & 0.75 \\
\hline & & all private sector & employer & all earnings & & 2.50 & 4.50 & 12.60 & 12.60 & 12.80 & 12.80 & 12.80 & 12.80 \\
\hline \multicolumn{14}{|l|}{ Panel D. Family benefits } \\
\hline Family benefits & CNAF & $\begin{array}{l}\text { all wage earners } \\
\text { all wage earners }\end{array}$ & $\begin{array}{l}\text { employer } \\
\text { employer }\end{array}$ & $\begin{array}{c}<\mathrm{SST} \\
\text { all earnings }\end{array}$ & 9.00 & 9.00 & 9.00 & - & - & - & - & - & \\
\hline
\end{tabular}

SST refers to the Social Security threshold (plafond de la sécurité sociale, in French) and 4 SST to four times this threshold. The SSCs presented in this table are the main SSCs for private sector wage earners. They do not include specific schemes such as regional schemes or various payroll taxes. Description of French acronyms for each scheme: CNAV: Caisse nationale d'assurance vieillesse; ARRCO: Association pour le régime de retraite complémentaire des salariés; AGIRC: Association générale des institutions de retraite des cadres ; CET Cotisation exceptionnelle et temporaire; UNEDIC: Union nationale interprofessionnelle pour l'emploi dans l'industrie et le commerce; ASF: Association pour la gestion de la structure financière; APEC: Association pour l'emploi des cadres; MMID: maladie, maternité, invalidité, décès; CNAF: Caisse nationale des allocations familiales. Details for every year with legislative references are available on the website of the Institut des Politiques Publiques (IPP): https://www.ipp.eu/en/tools/ipp-tax-and-benefit-tables/social-security-contributions/. 


\section{A.2 Uncapping of Payroll Taxes}

In the 1980s and 1990s, some of the payroll taxes were uncapped. As a result, the overall rate of contribution increased. Yet, this concerns the earnings above the cap i.e., who belong to the top 3 deciles of the earnings distribution. The payroll tax rates of the high-income deciles progressively caught up with those of the lower-income deciles. The health and family contributions were progressively uncapped between 1981 and 1984, and 1989 and 1990 as well as the contribution covering work-related injuries and retirement contributions in 1991.

\section{A.3 Payroll Tax Cuts around the Minimum Wage}

Starting in 1993, social security reductions were created for low incomes under 1.3 minimum wages. Since then, there has been a succession of reduction schemes (exonérations famille, ristourne Juppé, allègements Aubry et Fillon $\left.{ }^{19}\right)$. The maximum rate of reduction over the period is of $26 \%{ }^{20}$ of the gross wage and concerns employees paid at the minimum wage. The reduction schedules are such that the rate of reduction is the highest at the minimum wage level and decreases with the increase of the wage, until it fades away. The maximum level of wage giving the right to reductions ranged between 1.3 and 1.7 minimum wage.

In the context of high unemployment in 1998, a policy aimed at reducing working time, hoping that it would contribute to job creations. This led to many changes in the reduction scheme. Indeed, two different schedules prevailed between 2000 and 2003 for firms that implemented the reduction of the working time and for firms who did not. After 2003, the Fillon law framed the convergence of the two schedules and came about with a unified schedule for all firms.

Finally, a last reform has been enacted in 2013 in the form of a tax credit for the corporate income tax (CIT) called Crédit d'impôt pour la compétitivité et l'emploi (tax credit for competitiveness and jobs), or CICE for the French acronym. The CICE reduces nominally the CIT liability but is computed like a payroll tax cut as a percentage of individual earnings of firms liable to the CIT. In 2019 the CICE was converted into a payroll tax cut, underlying the similarity in the design of this policy. Nevertheless, it is unclear whether the impact of such CIT tax credit is really similar to previous cuts of payroll taxation. Another difference is that the CICE did not target specifically workers

\footnotetext{
${ }^{19}$ We do not calculate the Robien scheme of 1996 because of lack of information.

${ }^{20} 28.1 \%$ for firms with fewer than 20 employees.
} 
around the minimum wage, but encompassed earnings up to 2.5 times the minimum wage, with a flat rate schedule (i.e., a $6 \%$ cut for all earnings below that threshold).

\section{B Data, Micro-simulation, Sample Restrictions and Variables}

This section provides further details on the main sources of data used in the paper (Sections B.1.1 and B.1.2), the administrative payroll tax data (DADS), and the industry level data on capital and labor inputs (EU KLEMS). Second, we explain how we merge these data at the industry-year level (Section B.1.3). Third, we describe the micro-simulation software used to compute the payroll taxes (Section B.2). Fourth, we explain our sample selection B.3 and, last the variables' definition B.4.

\section{B.1 Data}

\section{B.1.1 DADS panel tous salariés and DADS EDP}

Worker-level information comes from two sources, payroll tax data for job-related variables, and census data for demographic variables.

Payroll tax data. For 1976-2015, wages and job-related information comes from the DADS panel tous salariés and education information from the EDP database. First, the DADS panel is a representative extraction of the DADS (Déclarations Annuelles de Données Sociales) data, which is the main administrative data source constructed by the French national statistical office (INSEE) from social security records on all private sector French workers (see Charnoz et al. (2011)). We used all the annual extractions, except for 1981, 1983 and 1990 years due to missing data and 1994 due to bad quality of the data. The panel contains individuals born in October of even years and who worked at least once in the private sector.

For 1967-1975, the DADS panel tous salariés does not exist. Instead, we rely on the DADS-Salariés, which is similar to the panel tous salariés in many regards. We call "DADS data" the payroll tax data composed of the DADS salariés for 1967-1975 and of the DADS panel tous salariés for 1976-2015. We compute payroll taxes on this database and use the results for all figures and tables showing payroll tax rates and inequality ratios. 
Census data. The EDP database (Échantillon Démographique Permanent) consists of demographic information, including the highest degree they obtained, for individuals born one of the four first days of October of even years. Information for these individuals have been retrieved from the census which took place for the whole population in 1968, 1975, 1982, 1990 and 1999 and for one fifth of the population according to a rotating sampling every year starting in 2003. The two databases are matched by the French statistical administration based on date of birth and names. The job-related variables being the same in the DADS panel and in the DADS-EDP panel, the following details on these concepts are relevant for both databases. We use this version of the data for analyses that use individuals' education.

\section{B.1.2 EU KLEMS}

The EU KLEMS data ${ }^{21}$ provides industry-level variables on output, capital and labor inputs and productivity for several countries. The data are available for 34 industry-levels categories, corresponding to the NACE Rev. 2 classification. We use the data for France, available since 1975 (1978 for the capital inputs variables).

\section{B.1.3 Matching EU KLEMS and DADS EDP at the Industry Level}

The industry-level analysis relies on a matching of EU KLEMS and DADS EDP data at the industry level. Some adjustments in the industry categories were necessary to construct a variable consistent over time and across database. We end up with a 31 levels classification, described in table B2.

Industry-level aggregation for EU KLEMS. We only modify the 34 levels classification by aggregating some categories in two cases. We aggregate the three levels (45; 46; 47 ) of the G category and the two levels $(49-52 ; 53)$ of the $\mathrm{H}$ category and obtain our 31 categories.

Industry-level aggregation for the DADS EDP. In the DADS, the definition of the industry category variable changes over time. An aggregated variable (ape40 up to 1993, a38 after 1994 ) of the detailed classification variable (NAP 73 to 1993, NAF between 1994 and 2002, NAF rev. 1 between, 2003 and 2008, NAF rev. 2 starting in 2009) is provided. We use the aggregated variable a38 after 1994. However, the aggregated variable of the

\footnotetext{
${ }^{21}$ Funded by the European Commission and freely available at http://euklems.net/
} 
beginning of the period (ape40) does not match well with the more recent aggregation (aligned on the NACE Rev. 2 classification). To deal with this issue, we rely on a mapping of the most detailed level of classification, provided by the National Institute of Statistics (INSEE). The mapping provides, for each new category, the share of establishments and the number of workers that belonged to each old category (and vice versa). We attribute to each old category the new category for which the number of workers is the highest. The precise category obtained is then converted into the corresponding aggregated variable (a38), that we aggregate at the 31 industry levels, as shown in B2. This task enables us to have consistent industry categories overtime, that we can then use for the matching with EU KLEMS. We drop the following industry levels : AZ (agriculture), TZ (household as employers) and UZ (extra-territorial activities) which are not covered during the whole period by the DADS. We also have to drop the JC category because there are not enough observations at the beginning of the period. We are left with 27 industry levels.

\section{B.2 Microsimulation of Payroll Taxes}

We compute the payroll taxes since 1967 by applying a microsimulation model on the information available in the DADS data. We use the TAXIPP model which is developed at the Institut des Politiques Publiques (IPP) and in particular the payroll tax module. The model applies the payroll tax schedule, as collected in the IPP Tax and Benefit Tables (Institut des Politiques Publiques, 2018), and computes employer and employee SSCs, reductions in employer SSCs, flat-rate income tax (CSG and CRDS) as well as other payroll taxes.

This exercise relies on ad hoc assumptions needed when applying the legislation to the raw data. We face two main challenges in computing payroll taxes from the DADS data. First, we have to use the net taxable earnings variable as the main input to the model, because it is the only earnings measure consistently available throughout the period. We then compute gross earnings, labor cost and net wage using the microsimulation model. Second, payroll taxes should be computed as a function of hourly wage. Since we do not observe working hours in the DADS data before 1993, the payroll taxes for part-time workers cannot be computed precisely before 1993. This is the reason why we focus on full-time workers.

We also use the microsimulation model to apply the income tax schedule to the taxable earnings so as to compute the amount of income tax that a worker would have paid, assuming that she is alone in her household and has no other source of income. This 
Table B2: Industry-level Classification

\begin{tabular}{|c|c|c|c|c|}
\hline $\begin{array}{l}\text { Industry } \\
\text { Levels }\end{array}$ & $\begin{array}{c}\text { Code } \\
\text { EUKLEMS }\end{array}$ & $\begin{array}{l}\text { ape40-DADS } \\
\text { Pre } 1993\end{array}$ & $\begin{array}{l}\text { a38-DADS } \\
\text { Post } 1994\end{array}$ & Label \\
\hline $\mathrm{AZ}$ & $\mathrm{A}$ & 1 & $\mathrm{AZ}$ & Agriculture, forestry and fishing \\
\hline BZ & B & $7-9$ & BZ & Mining and quarrying \\
\hline $\mathrm{CA}$ & $10-12$ & $2-3$ & $\mathrm{CA}$ & Food products, beverages and tobacco \\
\hline $\mathrm{CB}$ & $13-15$ & $18-19$ & $\mathrm{CB}$ & $\begin{array}{l}\text { Textiles, wearing apparel, leather and re- } \\
\text { lated prodcuts }\end{array}$ \\
\hline $\mathrm{CC}$ & $16-18$ & $20-22$ & $\mathrm{CC}$ & $\begin{array}{l}\text { Wood and paper products; printing and re- } \\
\text { production of recorded media }\end{array}$ \\
\hline $\mathrm{CD}$ & 19 & 4 & $\mathrm{CD}$ & Coke and refined petroleum products \\
\hline $\mathrm{CEF}$ & $20-21$ & $11-12$ & $\mathrm{CE}+\mathrm{CF}$ & Chemicals and chemical products \\
\hline CG & $22-23$ & 1023 & CG & $\begin{array}{l}\text { Rubber and plastics products, and other } \\
\text { non-metallic mineral products }\end{array}$ \\
\hline $\mathrm{CH}$ & $24-25$ & 13 & $\mathrm{CH}$ & $\begin{array}{l}\text { Basic metals and fabricated metal prod- } \\
\text { ucts, except machinery and equipment }\end{array}$ \\
\hline CIJ & $26-27$ & $15-16$ & $\mathrm{CI}+\mathrm{CJ}$ & Electrical and optical equipment \\
\hline CK & 28 & 14 & CK & Machinery and equipment n.e.c. \\
\hline CL & $29-30$ & 1719 & CL & Transport equipment \\
\hline $\mathrm{CM}$ & $31-33$ & & $\mathrm{CM}$ & $\begin{array}{l}\text { Other manufacturing; repair and installa- } \\
\text { tion of machinery and equipment }\end{array}$ \\
\hline $\mathrm{DE}$ & D-E & 56 & $\mathrm{DZ}+\mathrm{EZ}$ & Electricity, gas and water supply \\
\hline FZ & $\mathrm{F}$ & 24 & FZ & Construction \\
\hline GZ & $\mathrm{G}=45+46+47$ & $25-29$ & GZ & $\begin{array}{l}\text { Wholesale and retail trade; repair of motor } \\
\text { vehicles and motorcycles }\end{array}$ \\
\hline $\mathrm{HZ}$ & $\mathrm{H}=49-52+53$ & $31-32$ & $\mathrm{HZ}$ & Transportation and storage \\
\hline IZ & I & 30 & IZ & Accommodation and food service activities \\
\hline JA & $58-60$ & & JA & $\begin{array}{l}\text { Publishing, audiovisual and broadcasting } \\
\text { activities }\end{array}$ \\
\hline JB & 61 & & JB & Telecommunications \\
\hline $\mathrm{JC}$ & $62-63$ & & $\mathrm{JC}$ & IT and other information services \\
\hline $\mathrm{KZ}$ & $\mathrm{K}$ & 36 & $\mathrm{KZ}$ & Financial and insurance activities \\
\hline LZ & $\mathrm{L}$ & 37 & LZ & Real estate activities \\
\hline $\mathrm{MN}$ & $\mathrm{M}-\mathrm{N}$ & $33-34$ & $\mathrm{MA}+\mathrm{MB}+\mathrm{MC}+\mathrm{NZ}$ & $\begin{array}{l}\text { Professional, scientific, technical, adminis- } \\
\text { trative and support service activities }\end{array}$ \\
\hline $\mathrm{OZ}$ & $\mathrm{O}$ & 38 & $\mathrm{OZ}$ & $\begin{array}{l}\text { Public administration and defence; com- } \\
\text { pulsory social security }\end{array}$ \\
\hline $\mathrm{PZ}$ & $\mathrm{P}$ & & PZ & Education \\
\hline $\mathrm{Q}$ & $\mathrm{Q}$ & & $\mathrm{QA}+\mathrm{QB}$ & Health and social work \\
\hline RZ & $\mathrm{R}$ & & RZ & Arts, entertainment and recreation \\
\hline SZ & $\mathrm{S}$ & & $\mathrm{SZ}$ & Other service activities \\
\hline $\mathrm{TZ}$ & $\mathrm{T}$ & & $\mathrm{TZ}$ & Activities of households as employers \\
\hline $\mathrm{UZ}$ & $\mathrm{U}$ & & $\mathrm{UZ}$ & $\begin{array}{l}\text { Activities of extraterritorial organizations } \\
\text { and bodies }\end{array}$ \\
\hline
\end{tabular}

assumption is not trivial, but this computation serves our purpose which is to compare the changes in the payroll tax schedule and the income tax schedule. 


\section{B.3 Sample Restrictions}

To compute consistent measures of inequality over time, we have to overcome challenges related to the evolution of the DADS data in terms of the variables and observations it contains.

We operate sample restrictions to ensure that the composition of the sample is consistent over time and that we can compute correctly payroll taxes on the analysis sample during the whole period 1967-2015. We restrict our sample to jobs in the private sector, dropping the following categories of job that were missing from the data in the early years: (semi-)public sector, apprenticeship, internships, homework. We also drop unemployed workers who have been included in the dataset only in 2008. We finally remove workers paid less than $75 \%$ of the minimum wage, consistent with what is done in the literature. These workers may be under very specific working contracts that have not been removed by our previous trim, and the computation of payroll taxes for them can be subject to errors due to imperfect observation of their exact labor market situation.

We also restrict the sample to individuals working full-time and being observed in the same job an entire calendar year. The main reason for keeping only full-time workers is that contractual hours worked per year are only available in the data from 1993 onward. This prevents us from studying hourly wages for the whole period. To make sure that we observe wages (earnings per unit of time) which are much more relevant than earnings to study market explanations, we therefore have to restrict the analysis to individuals working full-time. Additionally, the computation of payroll taxes requires knowledge of the hourly wage because the thresholds at which the marginal payroll tax rate changes depend on hourly wages-contrary to the income tax. This means that we cannot compute payroll taxes and measure the labor cost of part-time workers before 1993.

The second restriction-keeping only workers observed an entire year in the same firm-is not mandatory. We apply it because it simplifies tremendously the computation of social security contributions, both for us in the micro-simulation model and for the administration officially in charge of the computation. This is in part because keeping full-time full-year workers removes multiple jobs owners for whom total payroll taxes are split across the different employers according to sophisticated rules that are difficult to apply to the data and that are also likely to be imperfectly applied by firms. Therefore, keeping only full-year workers makes us confident that we capture the true labor cost for all individuals observed in our final sample. We have nevertheless checked that including in the analysis workers not working an entire year in the same firm does not alter the paper's conclusions (results 
available upon request).

As a result of the sample restrictions, we drop roughly half of the individuals from the original datasets. Before selection, we have 497050 workers in 1967, 720100 in 1980 and 2318393 in 2015. Table B3 presents some descriptive statistics for 1967, 1980 and 2015.

Table B3: Descriptive Statistics - Payroll Tax Sample

\begin{tabular}{lcccccc}
\hline & \multicolumn{2}{c}{1967} & \multicolumn{2}{c}{1980} & \multicolumn{2}{c}{2015} \\
& Mean & Std Dev & Mean & Std Dev & Mean & Std Dev \\
\hline Labor cost & 20247 & 14797 & 34431 & 20398 & 48966 & 60120 \\
Gross wage & 16345 & 13816 & 25086 & 16803 & 35052 & 40311 \\
Net wage + contributions & 16349 & 14117 & 26812 & 17232 & 39096 & 40518 \\
Net wage & 15362 & 13520 & 22112 & 15482 & 27481 & 34936 \\
Net-of-income tax age & 12381 & 7657 & 18950 & 10371 & 24110 & 19968 \\
\hline Observations & 282740 & & 408536 & & 839517 & \\
\hline
\end{tabular}

Note: Earnings are in constant euros 2010.

SOURCES: DADS data 1967-2015

\section{B.4 Definition of Main Variables}

Earning and wage variables. The raw data about earnings in the DADS come under the form of annual "net taxable earnings" (earnings reported for income tax). This definition of earnings is net of payroll taxes and gross of income tax, except for the taxable part of the Contribution Sociale Généralisée (CSG). Earnings reported include basic earnings, as well as bonuses.

The net wage corresponds to the "net taxable earnings" before 1990. From 1991 onward (when the CSG is introduced), the net wage corresponds to the net taxable earnings less the (deductible part of the) CSG.

Gross wage corresponds to net wage plus all employee payroll taxes (see Figure ??). Gross wage is the contractual wage: it corresponds to the amount of pay stipulated in labor contracts, i.e., the posted wage, and on which negotiations typically take place. Gross wages are available in the DADS from 1993 onward, but we compute it for the entire period to keep consistent earnings definitions.

We call labor cost the actual cost paid per day worked full time by a firm for a given worker. It includes both employer and employee payroll taxes and has been entirely com- 
puted from net wages using TAXIPP.

Our measure of net wage concept from the DADS data is gross of income tax. As income taxation is in France assessed at the household level and thus depends on the family structure, it is not possible to derive an exact measure of the net-of-income tax wage. To estimate it, we apply the income tax schedule to taxable earnings, assuming that workers live in one-individual household and have no other source of income. Even though these assumptions lead to approximations, they will serve our purpose of providing a broad comparison of the evolution of the payroll tax and income tax schedules.

As we focus on workers for which we observe earnings corresponding to a full-time job during a full calendar year, we do not need to divide these earnings by hours worked to get wage concepts. We have however also divided earnings by the number of working days in a given employment spell (which are always observed in the DADS data). Daily wages are then used when individuals working only part of a calendar year in a given firm are also included in the analysis (this is only done as a robustness check not presented in the paper).

Education Variable. We use the variable (dip_tot) homogenized by the French National Institute of Statistics (INSEE) coming from the censuses. Following Abowd et al. (1999) and Charnoz et al. (2011), we use a breakdown of the highest diploma in eight categories. We then construct four education groups (right column of table 3). Unfortunately, the precision of the original census variable does not allow us to differentiate between graduates and postgraduates. We use a three-categories education variable: less than high school, high school graduates, more than high school.

Capital variables. Our ICT capital variable comes from EUKlems data (available since 1978). It is the sum of three variables (computing equipment, communications equipment and Computer software and databases). Our non ICT capital variable contains the rest of the capital variables available. We divided both the ICT capital and the non-ICT capital variables by the value added. 
Table B4: Education variable

\begin{tabular}{|c|c|c|c|}
\hline dip_tot & French Label & English Label & Education Variable \\
\hline 1 & $\begin{array}{l}\text { Aucun diplôme déclaré (aucun } \\
\text { diplôme ou pas présent au recensement) }\end{array}$ & No diploma & 1 \\
\hline 2 & CEP, DFEO & Elementary school & 1 \\
\hline 3 & BEPC, BE, BEPS & Junior High School & 1 \\
\hline 4 & $\begin{array}{l}\text { CAP, BEP, EFAA, BAA, BPA, FPA } \\
\text { Baccalauréats technique et professionnel, }\end{array}$ & Vocational basic & 1 \\
\hline 5 & $\begin{array}{l}\text { Brevet professionnel, autres brevets } \\
\text { BEA BEC BEH BEI BES BATA, }\end{array}$ & Vocational advanced & 2 \\
\hline 6 & Baccalauréat général, brevet supérieur, CFES & High School Graduate & 2 \\
\hline 7 & $\begin{array}{l}\text { BTS, DUT, DEST, DEUL, DEUS, DEUG, } \\
\text { diplôme professions sociales ou de la santé }\end{array}$ & Undergraduate university & 3 \\
\hline 8 & $\begin{array}{l}\text { Diplôme universitaire de 2ème ou 3ème } \\
\text { cycle, diplôme d'ingénieur, grande école }\end{array}$ & University Graduate & 3 \\
\hline
\end{tabular}

\section{Supply/Demand of Skills and Skill Biased Techni- cal Change}

This section describes the methodology of figure $3 \mathrm{a}$ and figure $3 \mathrm{~b}$ and the corresponding tables (D2 and D3). Using the DADS-EDP data, we construct two different samples, the wage sample aiming at measuring the relative wage gap, and the supply sample for the relative supply. Importantly, we only include in the sample the individuals who belong to the historical EDP panel (born on October 1-4 on even-numbered years), excluding individuals incorporated through the enlargement of the panel in 2002. This restriction ensures that we have comparable information before and after 2002. ${ }^{22}$ The wage sample contains individuals between 20 and 60 years old working full-time full-year in the private sector. In this sample, we trim the bottom part of the distribution by excluding people whose total annual earning is less than $75 \%$ of the minimum wage. The only restrictions on the supply sample are imposed by the data. Because unemployed individuals (receiving benefits) were only introduced in 2002, we have to drop them from the data in order to get consistent series. Yet we do not restrict the sample to full-year or full-time workers. Table C5 provides descriptive statistics for both samples.

\footnotetext{
${ }^{22}$ The education variable, coming from the census, has more missing observations after 2002.
} 
Table C5: Descriptive Statistics on the DADS-EDP Sample

(a) Wage sample

\begin{tabular}{lcccccc}
\hline & \multicolumn{2}{c}{1980} & \multicolumn{2}{c}{2000} & \multicolumn{2}{c}{2015} \\
& Mean & Std.Dev & Mean & Std.Dev & Mean & Std.Dev \\
\hline Net wage & 22087.05 & 14680.73 & 24782.35 & 21497.47 & 27686.87 & 25181.49 \\
Gross wage & 25062.01 & 16036.35 & 31246.17 & 25399.65 & 35335.13 & 30031.83 \\
Labour cost & 34408.86 & 19350.61 & 44528.79 & 36423.39 & 49575.48 & 45138.19 \\
Age & 37.32 & 10.98 & 40.04 & 9.68 & 43.60 & 9.46 \\
Share of Male & 0.65 & 0.48 & 0.63 & 0.48 & 0.60 & 0.49 \\
Education & & & & & & \\
Less than highschool & 0.81 & 0.39 & 0.63 & 0.48 & 0.48 & 0.50 \\
Highschool & 0.11 & 0.31 & 0.15 & 0.36 & 0.20 & 0.40 \\
More than highschool & 0.08 & 0.27 & 0.22 & 0.41 & 0.32 & 0.47 \\
\hline Observations & 46291 & \multicolumn{7}{c}{45731} \\
\hline
\end{tabular}

(b) Supply sample

\begin{tabular}{lcccccc}
\hline & \multicolumn{2}{c}{1980} & \multicolumn{2}{c}{2000} & \multicolumn{2}{c}{2015} \\
& Mean & Std.Dev & Mean & Std.Dev & Mean & Std.Dev \\
\hline Number of days worked & 264.73 & 133.00 & 241.25 & 138.89 & 265.44 & 134.01 \\
Age & 34.40 & 12.25 & 36.23 & 11.39 & 44.38 & 11.04 \\
Share of Male & 0.62 & 0.49 & 0.55 & 0.50 & 0.48 & 0.50 \\
Education & & & & & & 0.49 \\
Less than highschool & 0.79 & 0.41 & 0.61 & 0.50 & 0.50 \\
Highschool & 0.11 & 0.31 & 0.16 & 0.36 & 0.20 & 0.40 \\
More than highschool & 0.10 & 0.31 & 0.24 & 0.42 & 0.30 & 0.46 \\
\hline Observations & 91384 & & 149545 & & 152601 & \\
\hline
\end{tabular}

SourCES: DADS-EDP data 1976-2015

\section{C.1 Methodology on Time Series Evidence of Demand Shifts}

This paragraph describes the methodology of figure 3a and table D2. To a large extent, our methodology follows Autor et al. (2008), without the re-weighting component. Using the wage and supply samples described in the previous section, we construct time series of the average net wage and labor cost, and quantities of labor supplied by the education groups described in B. We then take the log of the ratio of these variables for high-skilled (at least some college) versus middle-skilled (high school graduate) or low-skilled (highschool dropouts) in order to obtain our log net wage gap, log labor cost gap and relative labor supply. The regression models estimated using these series are described in the main text. 


\section{C.2 Methodology on the Sector-level Evidence of the Role of ICT Capital}

This paragraph describes the methodology of figure $3 \mathrm{~b}$ and table D3. We follow the methodology proposed by Michaels et al. (2014) in order to demonstrate the role played by the ICT capital in the polarization of the labor market. They test whether the sectors in which ICT capital use increased the most are also the sectors where the demand of high skilled labor increased and middle-skilled labor decrease. While they rely on international data and propose many robustness checks, we only propose a simple one-country application of their method in order to provide direct evidence that the demand shift toward high-skilled workers in France is driven by technological change. Our contribution for France with respect to Michaels et al. (2014) is to match the EU KLEMS data with the DADS data in order to have measures of labor cost by skill groups since 1978, that is the very first year for which we have measures of capital inputs in EU KLEMS. Indeed, the information on labor compensation comes from the French labor force survey since 1982. However, the earnings variable from the labor force survey is the net wage, while we use the labor cost, and is capped before 1990. Another difference with Michaels et al. (2014) comes from our skill categories, that we choose to be consistent with our time-series evidence of demand shifts (cf ). While our middle-skill group contains only highschool graduates, they include also workers with any other diploma, except for the university graduates that constitute the high skill-skilled group. For the low-skilled group, we are left with vocational and lower school diploma (including secondary education) while they only have workers with no diploma. Their skill categories are directly coming from EUKlems, which have country-specific skill definition. Our definition for France is consistent with the one for several countries in EUKlems.

Empirical model and expectations We aim at testing the hypothesis that the increase in ICT technologies polarizes the labor market by increasing the demand for highly skilled workers while decreasing the demand for middle-skilled workers. For that purpose, Michaels et al. (2014) propose the following simple long differences estimations for $S=\{H, M, L\}$ at the industry $i$, year $t$ level :

$$
\Delta Z_{i t}^{S}=\beta_{0}+\beta_{1}^{S} \Delta(C / Q)_{i t}+\beta_{2}^{S} \Delta(K / Q)_{i t}+\beta_{3}^{S} \Delta \ln (Q)_{i t}+u_{i t}^{S}
$$

where 
- $H, M, L$ denotes the three skill groups (high, middle and low skill)

- $Z_{S}$ is the payroll share accruing to the skill group $S$

- $C, K$ and $Q$ are respectively ICT capital, non-ICT capital and value added.

Then, a positive $\beta_{1}^{H}$ associated with a negative $\beta_{1}^{M}$ would validate the polarization hypothesis because the larger the increase in ICT/VA over the period, the higher the increase in payroll share accruing to the high skill group while the same increase in ICT/VA would be associated with a decrease in the payroll share of the middle-skilled. The expectations regarding the sign of $\beta_{1}^{L}$ are unclear.

Application and results We aggregate the supply and wage sample at the industry level variable (defined in Section B.1.3). We construct the wage bill share by summing labor cost at the year $\mathrm{x}$ industry $\mathrm{x}$ education levels that we divide by the sum of the corresponding wage concept at the year $\mathrm{x}$ industry levels.

Figure 3b shows the 37-years change in wage bill share for the three-skill category with respect to the 37-years change in ICT capital over value added ratio at the industry level. Table D3 reports the results of the skill share regressions. The dependent variables are changes from 1978 to 2015 in the wage bill share of the low skilled (3 columns on the left), middle skilled ( 3 columns in the middle) and high skilled ( 3 columns on the right). The regressions are estimated by OLS on the 37 years changes ${ }^{23}$. Columns (1) report the coefficients on the constant. It indicates that, on average, there was between 1978 and 2015 a $28.2 \%$ increase in the high skilled share, a $4.3 \%$ increase in the middle skilled share and a $32.5 \%$ decrease in the low skilled share. Columns (2) includes the growth in ICT capital intensity while columns (3) include also changes in non ICT capital and in the log of the value added.

The coefficient on changes in ICT/VA have the expected sign and significance: strongly positively significant for high skilled, strongly negatively significant for middle skilled. For the low-skilled, the coefficients are negative with a lower significance, while the model is undecided regarding the sign of this coefficient. The coefficients confirm that industries in which ICT capital grew more were those with larger shifts toward the higher skilled and away the middle skilled while the low skilled category is probably less affected.

\footnotetext{
${ }^{23}$ The corresponding panel regressions results with year and industry fixed effects give consistent results.
} 


\section{Additional Tables and Figures}

Table D1: Changes in P90/P10 by Country, 1980-2015.

\begin{tabular}{lcccc}
\hline & 1980 & 2000 & 2015 & \% change, 1980-2015 \\
\hline Poland & 2.81 & 3.56 & 3.92 & 0.39 \\
United States & 3.83 & 4.49 & 5.04 & 0.32 \\
France labor cost & 2.76 & 3.22 & 3.59 & 0.30 \\
New Zealand &. & 2.62 & 2.97 & 0.29 \\
Sweden & 1.96 & 2.35 &. & 0.17 \\
United Kingdom & 2.99 & 3.46 & 3.50 & 0.17 \\
Finland & 2.83 & 3.01 & 3.29 & 0.16 \\
Australia & 2.47 & 2.41 & 2.56 & 0.04 \\
Italy &. & 2.22 & 2.21 & -0.01 \\
France net wage & 3.01 & 2.92 & 2.92 & -0.03 \\
\hline
\end{tabular}

SouRCES: Net, gross and labor cost wages from the DADS data 1980-2015 for France, gross wage from the OECD for the other countries. We complete missing years by linear interpolation. When the data are not available at the beginning or the end of the period, we use the closest year available (1984 and 1986 for New Zealand and Italy instead of 1980 by example). 
Table D2: Relative Wage Gap: Evidence of SBTC

(a) High skilled vs middle skilled

\begin{tabular}{lcccc}
\hline & \multicolumn{2}{c}{ Labor cost gap of H vs M } & \multicolumn{2}{c}{ Net wage gap of H vs M } \\
& $(1)$ & $(2)$ & $(3)$ & $(4)$ \\
\hline Relative supply of H vs M & $-0.286^{* * *}$ & $-0.191^{* * *}$ & $-0.234^{* * *}$ & $-0.132^{* *}$ \\
& $(0.036)$ & $(0.034)$ & $(0.040)$ & $(0.037)$ \\
Linear time trend & $0.010^{* * *}$ & $0.012^{* * *}$ & $0.007^{* * *}$ & $0.009^{* * *}$ \\
& $(0.001)$ & $(0.001)$ & $(0.001)$ & $(0.001)$ \\
Log(real min. wage) & & $-0.406^{* * *}$ & & $-0.475^{* * *}$ \\
& & $(0.106)$ & & $(0.116)$ \\
Unemployment rate (15-24 y.o.) & & -0.001 & & -0.001 \\
& & $(0.001)$ & & $(0.001)$ \\
Constant & $0.173^{* * *}$ & $3.932^{* * *}$ & $0.223^{* * *}$ & $4.616^{* * *}$ \\
& $(0.007)$ & $(0.971)$ & $(0.008)$ & $(1.066)$ \\
\hline Observations & 35 & 34 & 35 & 34 \\
$R^{2}$ & 0.955 & 0.972 & 0.888 & 0.932 \\
\hline
\end{tabular}

(b) High skilled vs low skilled

\begin{tabular}{lcccc}
\hline \hline & \multicolumn{2}{c}{ Labor cost gap of H vs L } & \multicolumn{2}{c}{ Net wage gap of H vs L } \\
& $(1)$ & $(2)$ & $(3)$ & $(4)$ \\
\hline Relative supply of H vs L & $-0.268^{* * *}$ & $-0.180^{* * *}$ & $-0.277^{* * *}$ & $-0.181^{* * *}$ \\
& $(0.039)$ & $(0.032)$ & $(0.045)$ & $(0.037)$ \\
Linear time trend & $0.012^{* * *}$ & $0.013^{* * *}$ & $0.009^{* * *}$ & $0.010^{* * *}$ \\
& $(0.002)$ & $(0.002)$ & $(0.002)$ & $(0.002)$ \\
Log(real min. wage) & & $-0.707^{* * *}$ & & $-0.811^{* * *}$ \\
& & $(0.129)$ & & $(0.151)$ \\
Unemployment rate (15-24 y.o.) & & 0.000 & & 0.000 \\
& & $(0.001)$ & & $(0.001)$ \\
Constant & -0.048 & $6.643^{* * *}$ & 0.022 & $7.685^{* * *}$ \\
& $(0.091)$ & $(1.207)$ & $(0.105)$ & $(1.405)$ \\
\hline Observations & 35 & 34 & 35 & 34 \\
$R^{2}$ & 0.666 & 0.848 & 0.890 & 0.951 \\
\hline \hline
\end{tabular}

(c) High skilled vs (middle+low) skilled

\begin{tabular}{lcccc}
\hline \hline & Labor cost gap of $\mathrm{H}$ vs M+L & \multicolumn{2}{c}{ Net wage gap of H vs M+L } \\
& $(1)$ & $(2)$ & $(3)$ & $(4)$ \\
\hline Relative supply of H vs M+L & $-0.261^{* * *}$ & $-0.173^{* * *}$ & $-0.270^{* * *}$ & $-0.174^{* * *}$ \\
& $(0.035)$ & $(0.029)$ & $(0.040)$ & $(0.033)$ \\
Linear time trend & $0.010^{* * *}$ & $0.011^{* * *}$ & $0.007^{* * *}$ & $0.009^{* * *}$ \\
& $(0.002)$ & $(0.001)$ & $(0.002)$ & $(0.001)$ \\
Log(real min. wage) & & $-0.663^{* * *}$ & & $-0.765^{* * *}$ \\
& & $(0.120)$ & $(0.137)$ & 0.000 \\
Unemployment rate (15-24 y.o.) & & 0.000 & $(0.001)$ \\
Constant & -0.099 & $(0.001)$ & & $7.216^{* * *}$ \\
& $(0.085)$ & $(1.123)$ & $(0.097)$ & $(1.281)$ \\
\hline Observations & 35 & 34 & 35 & 34 \\
$R^{2}$ & 0.688 & 0.860 & 0.888 & 0.953 \\
\hline \hline
\end{tabular}

NotE: The table shows time series regression results corresponding to relative supply and relative net wage and labor cost gaps series shown in figure 3a. H, M and L are abbreviations standing for "high skilled", "middle skilled" and "low skilled". Standard errors in parentheses. ${ }^{*} p<0.05 ;{ }^{* *} p<0.01$; *** $p<0.001$.

SOURCES: DADS-EDP data 1976-2015. 
Table D3: Sector-level Wage Bill Share: the Role of ICT Capital, 1978-2015

\begin{tabular}{|c|c|c|c|c|c|c|c|c|c|}
\hline & \multicolumn{3}{|c|}{ "Low-skilled wage bill share } & \multicolumn{3}{|c|}{ Medium-skilled wage bill share } & \multicolumn{3}{|c|}{ High-skilled wage bill share } \\
\hline & $(1)$ & $(2)$ & $(3)$ & $(1)$ & $(2)$ & $(3)$ & $(1)$ & $(2)$ & $(3)$ \\
\hline Change in ICT/VA & & $\begin{array}{l}-1.433^{*} \\
(0.564)\end{array}$ & $\begin{array}{c}-1.636^{* *} \\
(0.526)\end{array}$ & & $\begin{array}{c}-0.875^{* * *} \\
(0.191)\end{array}$ & $\begin{array}{c}-0.828^{* * *} \\
(0.171)\end{array}$ & & $\begin{array}{l}2.308^{* *} \\
(0.691)\end{array}$ & $\begin{array}{c}2.464^{* * *} \\
(0.614)\end{array}$ \\
\hline Change in non ICT/VA & & & $\begin{array}{l}0.0196 \\
(0.018)\end{array}$ & & & $\begin{array}{r}-0.0177 \\
(0.009)\end{array}$ & & & $\begin{array}{c}-0.00185 \\
(0.023)\end{array}$ \\
\hline Change in $\ln (\mathrm{VA})$ & & & $\begin{array}{c}-0.0266 \\
(0.031)\end{array}$ & & & $\begin{array}{c}-0.0239^{*} \\
(0.011)\end{array}$ & & & $\begin{array}{l}0.0506 \\
(0.035)\end{array}$ \\
\hline Constant & $\begin{array}{c}-0.343^{* * *} \\
(0.023)\end{array}$ & $\begin{array}{c}-0.300 * * * \\
(0.033)\end{array}$ & $\begin{array}{c}-0.257^{* * *} \\
(0.045)\end{array}$ & $\begin{array}{c}0.0459^{* * *} \\
(0.010)\end{array}$ & $\begin{array}{c}0.0721^{* * *} \\
(0.009)\end{array}$ & $\begin{array}{c}0.109^{* * *} \\
(0.015)\end{array}$ & $\begin{array}{c}0.298^{* * *} \\
(0.028)\end{array}$ & $\begin{array}{c}0.228^{* * *} \\
(0.036)\end{array}$ & $\begin{array}{c}0.148^{* *} \\
(0.047)\end{array}$ \\
\hline Observations & 27 & 27 & 27 & 27 & 27 & 27 & 27 & 27 & 27 \\
\hline$R^{2}$ & 0.000 & 0.154 & 0.245 & 0.000 & 0.323 & 0.414 & 0.000 & 0.276 & 0.353 \\
\hline
\end{tabular}

SourCES: DADS-EDP data 1976-2015 and EUKlems data 1978-2015

NOTE: The table shows OLS regressions corresponding to figure $3 \mathrm{~b}$. The outcomes are the 37 years changes in sector-level wage bill share accruing to low-, middle- and high-skilled (column 3 ) workers in the 27 sectors. Standard errors in parentheses. ${ }^{*} p<0.05 ;^{* *} p<0.01{ }^{* * *} p<0.001$.

Table D4: Correlations Between the inequality Ratios and the Minimum Wage (Net Wage Concept)

\begin{tabular}{lccc}
\hline & \multicolumn{3}{c}{$\log ($ real minimum wage } \\
& Raw series & De-detrended & First difference \\
\hline $\log (\mathrm{P} 90 / \mathrm{P} 10)$ & -0.981 & -0.948 & -0.612 \\
$\log (\mathrm{P} 50 / \mathrm{P} 10)$ & -0.986 & -0.944 & -0.795 \\
$\log (\mathrm{P} 90 / \mathrm{P} 50)$ & -0.676 & -0.800 & -0.210 \\
\hline
\end{tabular}

\section{SOURCE: DADS}

NotE: Each column shows the correlation between the log of the net minimum wage and three different inequality ratios in logs for the net wage. The first column corresponds to the raw data. The second column contains de-trended series (for both the minimum wage and the inequality ratio) corresponding to the residuals from separate OLS regressions of the corresponding variable on a constant and a linear time trend. The last column shows the the correlation between first-differenced variables. 
Table D5: Comparing how Payroll Taxes and Income Taxes Contribute to Changes in the Relative Tax Wedge at Different Percentiles over the Period 1967-2015

\begin{tabular}{|c|c|c|c|c|c|}
\hline \multirow{2}{*}{$\begin{array}{l}\text { Inequality } \\
\text { measure }\end{array}$} & \multicolumn{3}{|c|}{ Variations (in log points) } & \multicolumn{2}{|c|}{$\begin{array}{l}\text { Contribution to changes in } \\
\text { relative tax wedge of changes in }\end{array}$} \\
\hline & $\begin{array}{c}\text { Labor cost } \\
\text { inequality } \\
\text { (1) }\end{array}$ & $\begin{array}{c}\text { Net wage } \\
\text { inequality } \\
(2)\end{array}$ & $\begin{array}{l}\text { income tax } \\
\text { wage } \\
\text { inequality } \\
(3)\end{array}$ & $\begin{array}{l}\text { Payroll } \\
\text { taxation } \\
\frac{(1)-(2)}{(1)-(3)}\end{array}$ & $\begin{array}{l}\text { Income } \\
\text { taxation } \\
\frac{(2)-(3)}{(1)-(3)}\end{array}$ \\
\hline \multicolumn{6}{|c|}{ (a) Between 1967 and 2015} \\
\hline $\begin{array}{l}\mathrm{P} 90 / \mathrm{P} 10 \\
\mathrm{P} 90 / \mathrm{P} 50 \\
\mathrm{P} 50 / \mathrm{P} 10 \\
\mathrm{P} 99 / \mathrm{P} 50 \\
\mathrm{P} 99.9 / \mathrm{P} 50 \\
\mathrm{P} 99.99 / \mathrm{P} 50\end{array}$ & $\begin{array}{c}0.081 \\
0.108 \\
-0.027 \\
0.106 \\
0.344 \\
0.716\end{array}$ & $\begin{array}{l}-0.234 \\
-0.039 \\
-0.195 \\
-0.132 \\
0.091 \\
0.522\end{array}$ & $\begin{array}{c}-0.165 \\
-0.010 \\
-0.155 \\
-0.029 \\
0.211 \\
0.622\end{array}$ & $\begin{array}{l}127.95 \% \\
124.37 \% \\
131.27 \% \\
176.20 \% \\
190.65 \% \\
206.90 \%\end{array}$ & $\begin{array}{l}-27.95 \% \\
-24.37 \% \\
-31.27 \% \\
-76.20 \% \\
-90.65 \% \\
-106.90 \%\end{array}$ \\
\hline \multicolumn{6}{|c|}{ (b) Between 1980 and 2015} \\
\hline $\begin{array}{l}\mathrm{P} 90 / \mathrm{P} 10 \\
\mathrm{P} 90 / \mathrm{P} 50 \\
\mathrm{P} 50 / \mathrm{P} 10 \\
\mathrm{P} 99 / \mathrm{P} 50 \\
\mathrm{P} 99.9 / \mathrm{P} 50 \\
\mathrm{P} 99.99 / \mathrm{P} 50\end{array}$ & $\begin{array}{l}0.265 \\
0.172 \\
0.093 \\
0.255 \\
0.580 \\
1.158\end{array}$ & $\begin{array}{c}-0.031 \\
0.039 \\
-0.071 \\
0.050 \\
0.353 \\
1.002\end{array}$ & $\begin{array}{c}-0.015 \\
0.038 \\
-0.053 \\
0.054 \\
0.279 \\
0.888\end{array}$ & $\begin{array}{c}105.66 \% \\
98.72 \% \\
112.04 \% \\
102.25 \% \\
75.23 \% \\
57.78 \%\end{array}$ & $\begin{array}{c}-5.66 \% \\
1.28 \% \\
-12.04 \% \\
-2.25 \% \\
24.77 \% \\
42.22 \%\end{array}$ \\
\hline \multicolumn{6}{|c|}{ (c) Between 1967 and 1980} \\
\hline $\begin{array}{l}\mathrm{P} 90 / \mathrm{P} 10 \\
\mathrm{P} 90 / \mathrm{P} 50 \\
\mathrm{P} 50 / \mathrm{P} 10 \\
\mathrm{P} 99 / \mathrm{P} 50 \\
\mathrm{P} 99.9 / \mathrm{P} 50 \\
\mathrm{P} 99.99 / \mathrm{P} 50\end{array}$ & $\begin{array}{l}-0.184 \\
-0.064 \\
-0.120 \\
-0.149 \\
-0.236 \\
-0.442\end{array}$ & $\begin{array}{l}-0.202 \\
-0.078 \\
-0.124 \\
-0.182 \\
-0.262 \\
-0.480\end{array}$ & $\begin{array}{l}-0.149 \\
-0.048 \\
-0.102 \\
-0.084 \\
-0.067 \\
-0.266\end{array}$ & $\begin{array}{l}-54.54 \% \\
-91.72 \% \\
-22.16 \% \\
-51.82 \% \\
-15.61 \% \\
-21.75 \%\end{array}$ & $\begin{array}{l}154.54 \% \\
191.72 \% \\
122.16 \% \\
151.82 \% \\
115.61 \% \\
121.75 \%\end{array}$ \\
\hline
\end{tabular}

Note: The table reports long-run changes (in log points) in the ratios of various percentiles of the labor cost, net wage and net-of-income tax wage inequality. It also shows how payroll taxation and income taxation contributed to the fact that net-of-income tax wage inequality did not evolve like labor cost inequality. More formally, note $z_{p_{i}}, w_{p_{i}}$ and $n_{p_{i}}$ the values of the labor cost, net wage and net-of-income tax wage at percentile $p_{i}$. Column (1) shows time variations $\Delta_{t_{1}}^{t_{2}} \ln \left(\frac{z_{p_{1}}}{z_{p_{2}}}\right)$ where $p_{1}$ and $p_{2}$ are the two percentiles given in the first column and the dates $t_{1}$ and $t_{2}$ are given in the title of each panel of the table. Similarly, columns (2) and (3) show variations $\Delta_{t_{1}}^{t_{2}} \ln \left(\frac{w_{p_{1}}}{w_{p_{2}}}\right)$ and $\Delta_{t_{1}}^{t_{2}} \ln \left(\frac{n_{p_{1}}}{n_{p_{2}}}\right)$, respectively. The last two columns rely on the fact that $\Delta_{t_{1}}^{t_{2}} \ln \left(\frac{z_{p_{1}}}{z_{p_{2}}}\right)=\Delta_{t_{1}}^{t_{2}} \ln \left(\frac{w_{p_{1}}}{w_{p_{2}}}\right)+\Delta_{t_{1}}^{t_{2}} \ln \left(\frac{1+\tau_{p_{1}}^{\text {payroll }}}{1+\tau_{p_{2}}^{\text {payroll }}}\right)=\Delta_{t_{1}}^{t_{2}} \ln \left(\frac{n_{p_{1}}}{n_{p_{2}}}\right)+\Delta_{t_{1}}^{t_{2}} \ln \left(\frac{1+\tau_{p_{1}}^{\text {income }}}{1+\tau_{p_{2}}^{\text {income }}}\right)+\Delta_{t_{1}}^{t_{2}} \ln \left(\frac{1+\tau_{p_{1}}^{\text {payroll }}}{1+\tau_{p_{2}}^{\text {payroll }}}\right)$, with $\tau_{p_{i}}^{\text {income }}$ and $\tau_{p_{i}}^{\text {payroll }}$ the average income and payroll tax rates at percentile $p_{i}$. They show $\frac{\Delta_{t_{1}}^{t_{2}} \ln \left(\frac{z_{p_{1}}}{z_{p_{2}}}\right)-\Delta_{t_{1}}^{t_{2}} \ln \left(\frac{w_{p_{1}}}{w_{p_{2}}}\right)}{\Delta_{t_{1}}^{t_{2}} \ln \left(\frac{z_{1}}{z_{p_{2}}}\right)-\Delta_{t_{1}}^{t_{2}} \ln \left(\frac{n_{1}}{z_{p_{2}}}\right)}$ and $\frac{\Delta_{t_{1}}^{t_{2}} \ln \left(\frac{w_{p_{1}}}{w_{p_{2}}}\right)-\Delta_{t_{1}}^{t_{2}} \ln \left(\frac{n_{p_{1}}}{n_{p_{2}}}\right)}{\Delta_{t_{1}}^{t_{2}} \ln \left(\frac{z_{1} p_{1}}{z_{p_{2}}}\right)-\Delta_{t_{1}}^{t_{2}} \ln \left(\frac{n_{p_{1}}}{n_{p_{2}}}\right)}$, respectively, after multiplying these proportions by 100 to get percentages. This decomposition provides the respective contribution of payroll and income taxation to the long-run changes in the relative tax wedge observed at different percentiles and therefore to the fact that labor cost and net-of-income tax wage inequality did not evolve similarly.

SOURCE: DADS data 1967, 1980 and 2015 
Figure D1: Average Payroll Tax Rates in France

(a) Selected percentiles

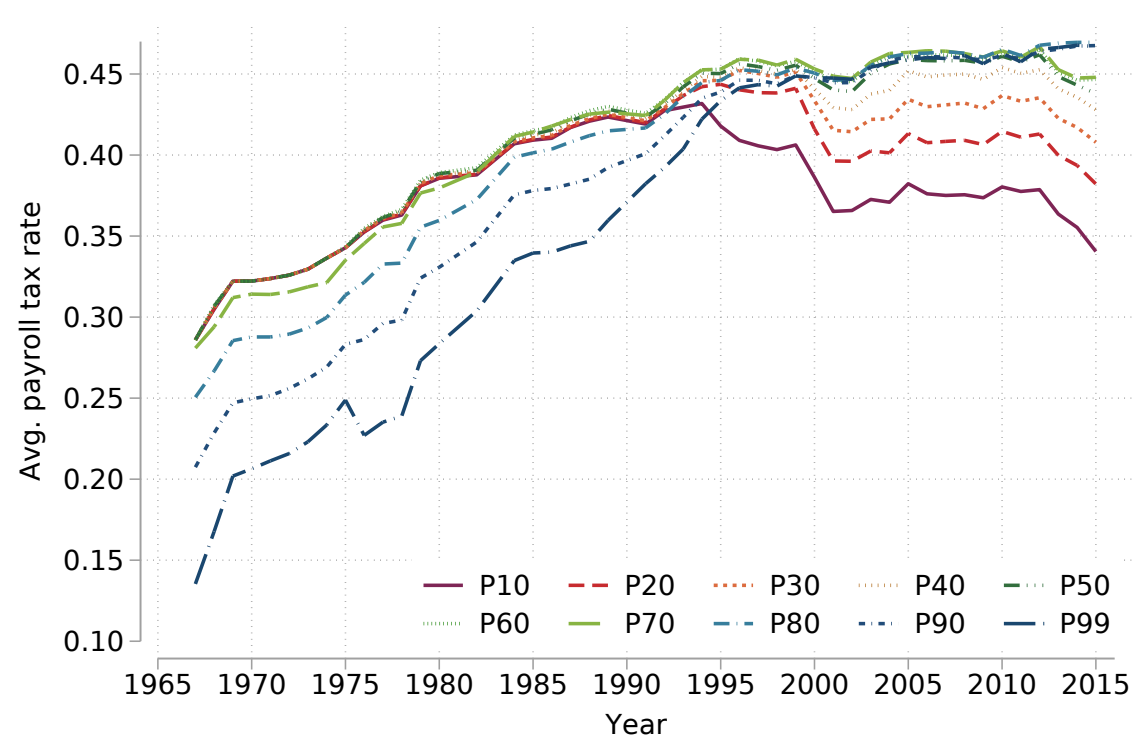

(b) Selected Years

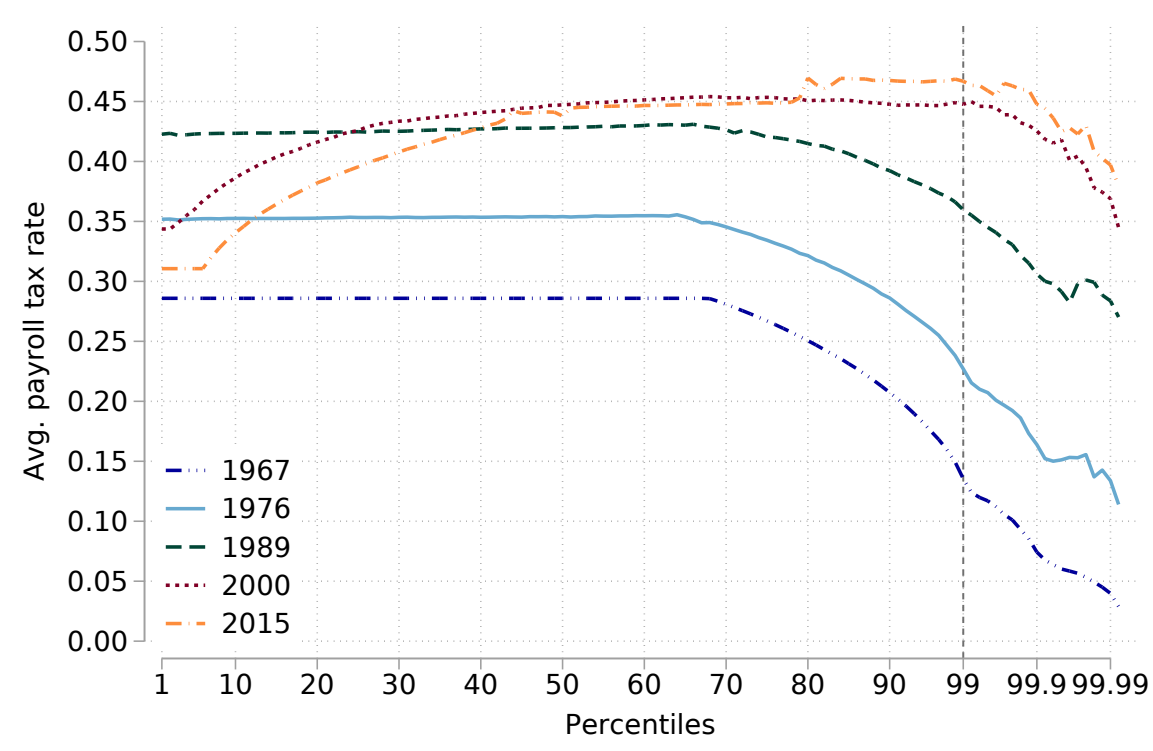

Notes: Panel (a) provides the ratio of the average total social security contributions (employer and employee part) to the average labor cost at selected percentiles of the labor cost distribution. Panel (b) shows the same indicator with respect to detailed percentiles of the labor cost distribution for 5 years since 1967. The vertical line at 99 denotes a change in the $\mathrm{x}$-axis scale.

Source: DADS data 1967-2015. The sample includes men and women between 20 and 64 years old working in the private sector. 
Figure D2: Wage Inequality (P90/P10 log Gross Wage Ratio)

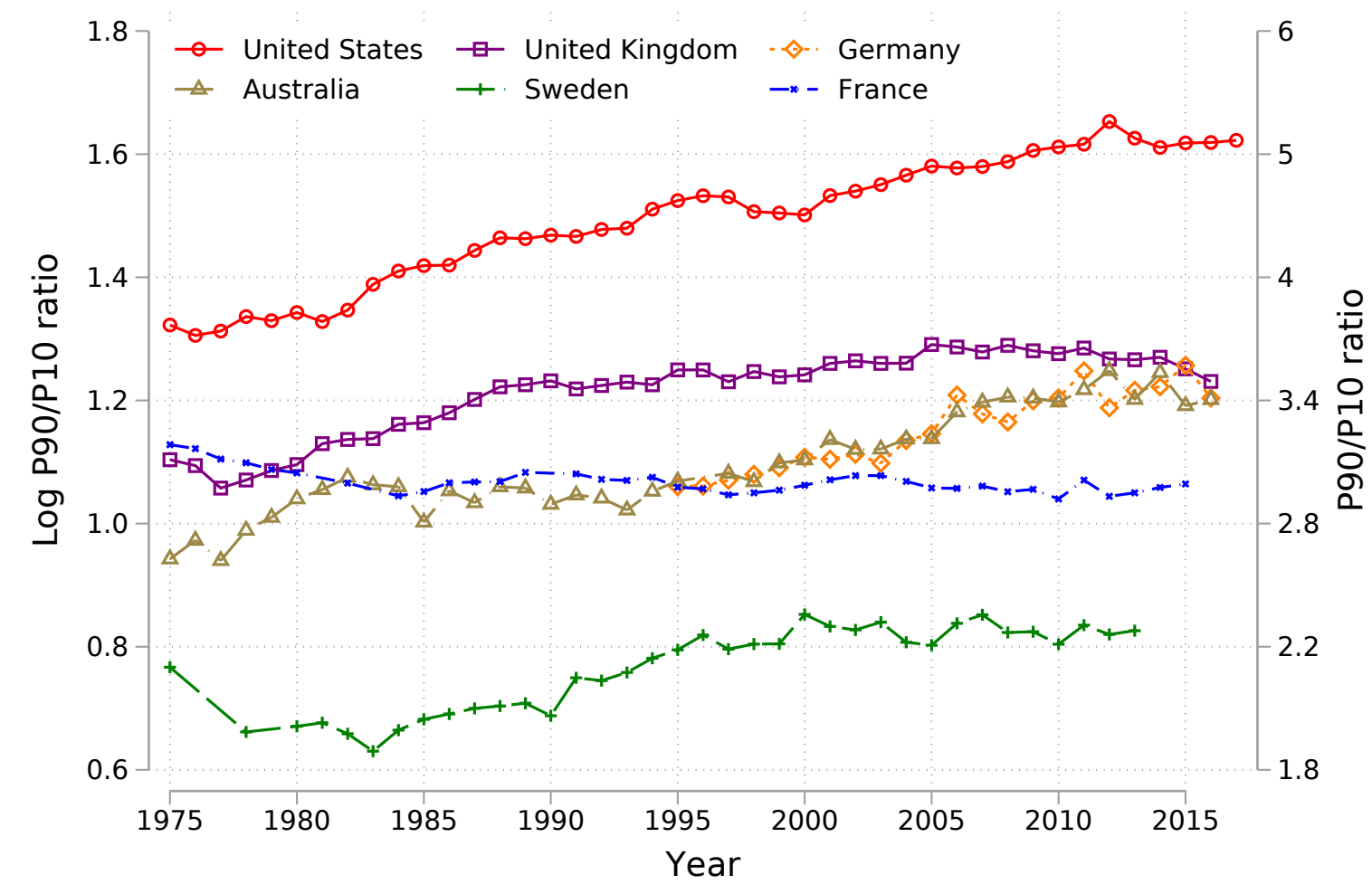

SourCE: : OECD statistics except for France (DADS data 1967-2015).

SAMPLE: : men and women working full-time full-year in the private sector. 
Figure D3: Evolution of the Share of Graduates in Employed Population in France, the U.K. and the U.S.

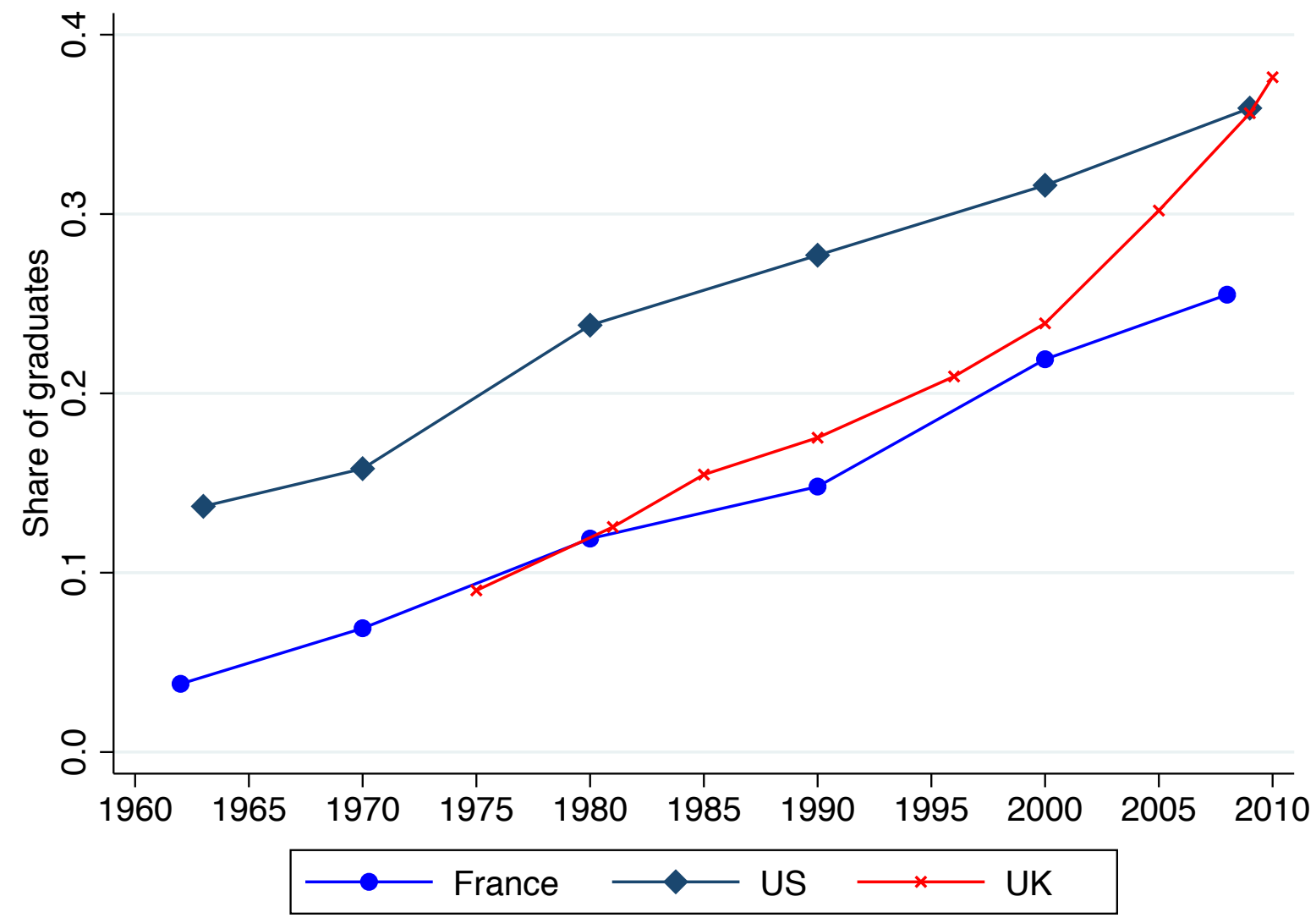

NotE: The figure shows the share of graduates in the employed population for France, the US and the UK.

SourCE: The data for the US come from Lindley \& Machin (2011) who use March CPS data. The data for France come from Verdugo (2014) who uses the DADS-EDP. The data for the UK come from own computation using the Labour Force Survey. 
Figure D4: Detrended net P90/P10, net P90/P50 and net minimum wage: 1967-2015

(a) $\mathrm{P} 90 / \mathrm{P} 10$

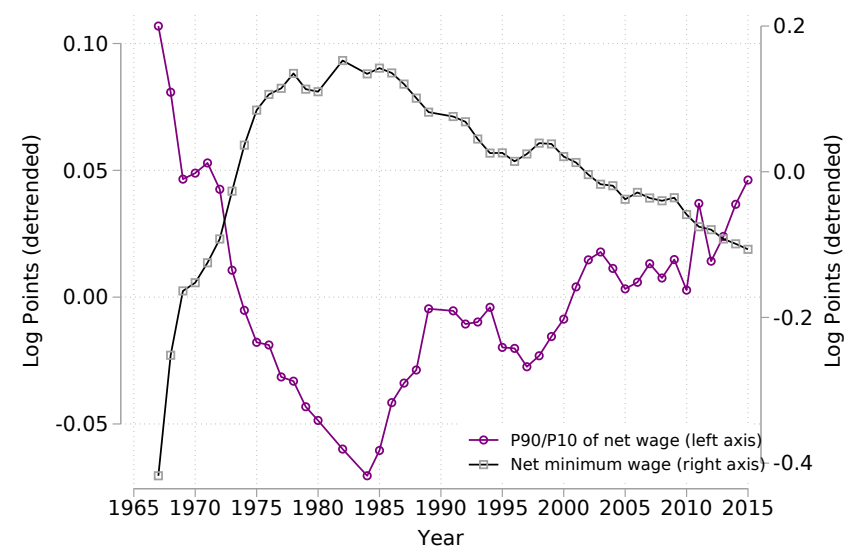

(b) P90/P50

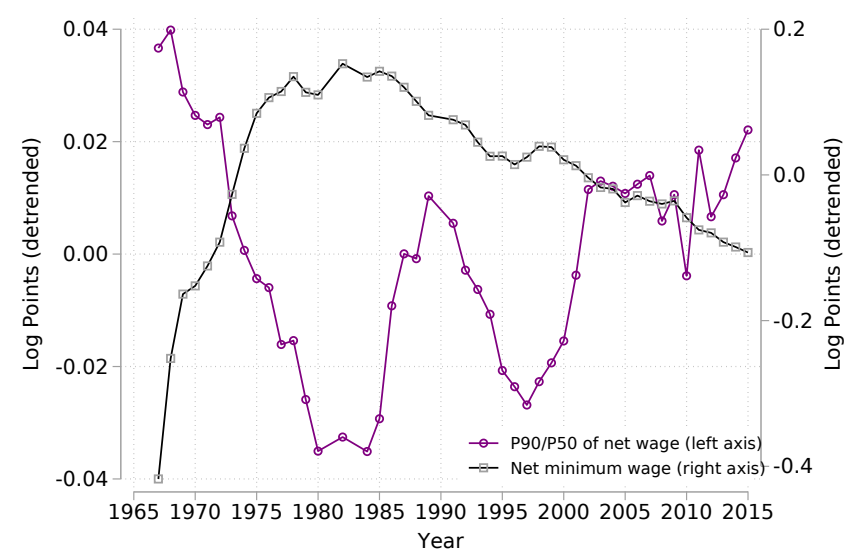

SOURCE: DADS data 1967-2015.

NotE: the figures shows the co-evolution of detrended log real net minimum wage (right axis) and detrended log net P90/P10 (panel a) or detrended log net P90/P50 (panel b). All series are in logs and are de-trended. The minimum wage is expressed in real terms. 
Figure D5: Evolution of Unemployment Rate

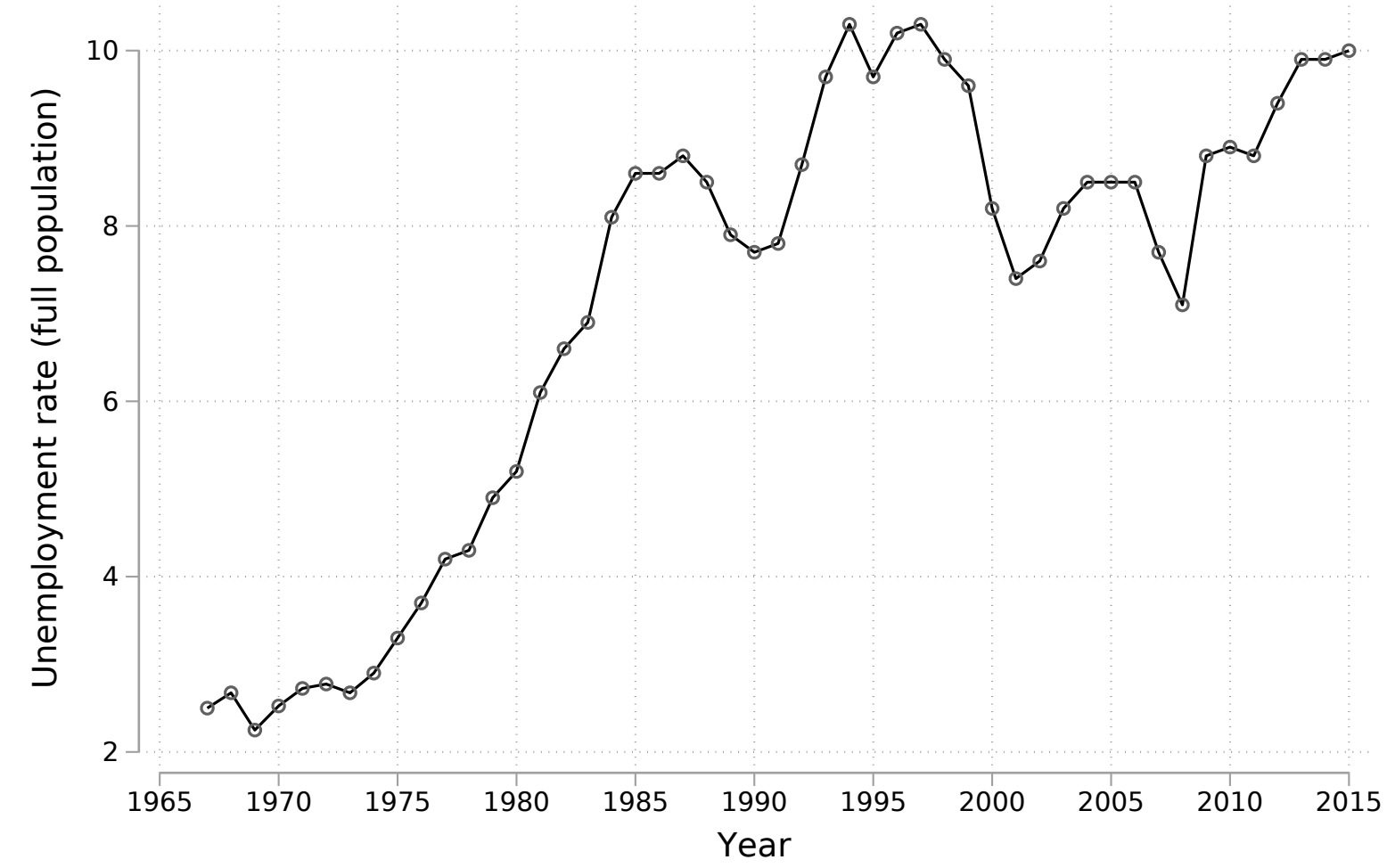

SOURCE: INSEE. 